\title{
Reconstruction of Mediterranean flora, vegetation and climate for the last 23 million years based on an extensive pollen dataset
}

\author{
Jean-Pierre SUC ${ }^{1 *}$, Speranta-Maria POPESCU², Séverine FAUQUETTE ${ }^{3}$, \\ Mostefa BESSEDIK ${ }^{4}$, Gonzalo JIMÉNEZ-MORENO ${ }^{5}$, Naima BACHIRI TAOUFIQ ${ }^{6}$, \\ Zhuo ZHENG', Frédéric MÉDAIL" ${ }^{8}$, Stefan KLOTZ ${ }^{9}$
}

1. Sorbonne Universités, UPMC Univ. Paris 06, CNRS, Institut des Sciences de la Terre Paris (iSTeP), 4 place Jussieu, 75005, Paris, France.

2. GeoBioStratData Consulting, 385 route du Mas Rillier, 69140 Rillieux-la-Pape, France.

3. ISEM, CNRS, Univ. Montpellier, IRD, EPHE, Montpellier, France.

4. Université d'Oran 2 Mohamed Ben Ahmed, Département des Sciences de la Terre, Laboratoire de Paléontologie stratigraphique et Paléoenvironnement, BP 1015, El M’Naouer, Oran, Algeria.

5. Departamento de Estratigrafía y Paleontología, Universidad de Granada, Fuenta Nueva S/N, 18002 Granada, Spain.

6. University Hassan II-Mohammedia, Faculty of Sciences Ben M'Sik, Casablanca, Morocco.

7. Department of Earth Sciences, Sun Yat-sen University, Guangzhou 510275, China.

8. Aix-Marseille Université, Avignon Université, CNRS, IRD, IMBE. Technopôle de I'Arbois-Méditerranée, BP 80, F-13545 Aix-en-Provence cedex 4, France.

9. Institut für Geowissenschaften, Universität Tübingen, Sigwartstrasse 10, 72070 Tübingen, Germany. * Corresponding author: jeanpierre.suc@gmail.com

\begin{abstract}
In the last 46 years extensive effort has been devoted to the botanical identification of pollen grains from Neogene deposits. This robust approach is the only reliable way to reconstruct past flora and vegetation from pollen archives, additionally allowing fruitful comparisons with plant macroremains. Rich peri-Mediterranean fossil pollen data provide a comprehensive history of plant ecosystems during the last 23 million years. Successive disappearance of thermophilous-hygrophilous taxa has occurred. Severe changes affected the North Mediterranean vegetation which varied from prevalent forests to dominant open environments. Avicennia mangrove progressively perished from North to South and was replaced by Glyptostrobus swamps which
\end{abstract}

Keywords: palynology and botany, history of taxa and plant ecosystems, climate quantifications. in turn disappeared too in a diachronous way. Subtropical evergreen forests left room for Mediterranean sclerophyllous communities, and finally to Artemisia steppes which alternated with mesophilous forests during glacial-interglacial cycles. The South Mediterranean plant ecosystems contrasted with open subdesertic associations where Avicennia persisted up to the early Pliocene before the steppes invaded the lowlands. Neogene climate changes benefited the Mediterranean sclerophyllous plants that were already present in the early Miocene. Their subsequent fluctuations relate not only to temperature variations but maybe also to phases with high instability in seasonality and low variability in warmth. When present, Microtropis fallax is a serious candidate for identifying the primary Mediterranean sclerophyllous assemblages. Interpretation and climate quantification of the pollen data show a well-marked latitudinal contrast in the Mediterranean area both in temperature and humidity/dryness. The thermic latitudinal gradient is characterized 
by a significant increase in the late Miocene towards its modern value. In the late Pliocene, climate evolved from overall warm temperatures and dry seasons to cooler winters and dry summers. General dryness and colder conditions developed during glacial periods, alternating with moister and warmer conditions during interglacials. Present refuges of Zelkova and Pterocarya are discussed. Desiccation of the Mediterranean led subdesertic plants and cedar to migrate in opposite ways. The present distribution of Cedrus illustrates its weakness against coolings although it seems to have been saved by geodynamic events.

\section{Version abrégée}

Cette synthèse, qui repose sur l'analyse de plus de 220 flores polliniques (figure 1), résume trente-sept années de collaboration avec Pierre Quézel (1926-2015), Professeur à l'univesité d'Aix-Marseille, qui ont été marquées par vingt-huit travaux académiques (table 1). Après un effort unique en vue de l'identification botanique des grains de pollen du Néogène, plus de 260 taxa (dont 74 nouveaux) sont aujourd'hui inventoriés dans le Cénozoïque supérieur de Méditerranée (table 2). Il est désormais démontré qu'il s'agit de la meilleure approche à même de retracer l'histoire de la flore et de la végétation des derniers 23 millions d'années (Ma), favorisant en plus la comparaison avec les macroflores. Cet article se veut un plaidoyer pour l'abandon par quelques palynologues d'une approche inadaptée et dont on devrait mettre en cause la forte homogénéité des résultats incompatible avec l'hétérogénéité des paléoenvironnements.

Le caractère diachrone des extinctions de taxa thermophiles et hygrophiles est détaillé selon la latitude et la longitude. Les flores polliniques de Méditerranée nord-occidentale fournissent un exemple significatif des remplacements successifs des écosystèmes végétaux (figures $2 \& 3$ ) : la mangrove appauvrie à Avicennia remplacée sur les littoraux du Serravallien par les marécages à Glyptostrobus qui disparaîtront à leur tour au Pliocène ; le relais des forêts sclérophylles par les groupements xérophytiques au Pliocène supérieur; l'invasion par les steppes à Artemisia signant les premières glaciations de l'hémisphère nord à 2,6 Ma qui désormais alterneront avec les forêts mésophiles des interglaciaires. Le diachronisme latitudinallongitudinal de ces remplacements est illustré à l'échelle de toute la région méditerranéenne (figure 4). Le domaine sud-méditeranéen était différent avec des environnements ouverts, subdésertiques (avec Lygeum, Calligonum, Neurada, Nitraria, Ziziphus), où Avicennia persista jusqu'au Pliocène inférieur avant l'invasion généralisée par les steppes à Artemisia. Les xérophytes méditerranéennes (Olea, Phillyrea, Ceratonia, Pistacia, Nerium, Quercus type ilex, etc.), présentes dès le début du Miocène, bénéficièrent de cette évolution puis, lors de refroidissements, tirèrent peutêtre partie de certaines phases de grande instabilité dans la saisonnalité et de faible variabilité de la chaleur reçue en relation avec certains paramètres astronomiques (respectivement, forte amplitude de l'obliquité et faible amplitude de l'excentricité) (figures 5-7). Avant sa disparition du domaine nord-méditerranéen, Microtropis fallax (Celastraceae), vivant aujourd'hui dans la forêt sempervirente à larges feuilles du Viêt-Nam mais sous sécheresse estivale, doit être considéré pour illustrer les groupements xérophytiques primitifs. En Camargue, l'expansion des xérophytes méditerranéennes est intervenue plus de 2000 ans avant les premiers signes d'activité anthropique, apportant un nouvel argument dans le débat sur le rôle respectif du climat et de l'action humaine dans leur récente expansion qui, comme pour les steppes, peut être due d'abord au climat avant d'être encouragée par la pression anthropique (figure 8).

L'évolution climatique déduite des flores polliniques peut être subdivisée en trois phases majeures :

- du Miocène au début du Pliocène supérieur (23 - 3,37 Ma), un certain rythme climatique existait avec une saison sèche (avec des variantes selon l'âge et la situation géographique) dans un contexte subtropical à faible saisonnalité thermique ;

- la période 3,37 - 2,6 Ma peut être regardée comme une phase de transition au cours de laquelle un rythme saisonnier méditerranéen (à sécheresse estivale et froids hivernaux) a été expérimenté ;

- la mise en place des glaciations de l'hémisphère Nord à 2,6 Ma entraînèrent la généralisation de la xéricité et du froid avec des saisons très contrastées tandis que les interglaciaires étaient plus doux et plus humides.

Les quantifications confirment l'existence dès le Miocène moyen d'un gradient latitudinal très marqué, à la fois en température et en sécheresse-humidité (figure 9). Peu après le gradient thermique latitudinal connut une augmentation vers sa valeur actuelle. La 
dessiccation quasi totale de la Méditerranée à la fin du Miocène (5,6 - 5,46 Ma) ne s'est pas traduite par des bouleversements climatiques drastiques dans cette région et, du point de vue de la végétation, semble se résumer en l'état de nos connaissances encore partielles (1) à la migration des éléments subdésertiques vers des milieux septentrionaux moins défavorables et (2) à l'opportunité offerte à Cedrus atlantica d'un passage en Afrique du Nord.

L'aire relictuelle actuelle de Zelkova (Ulmaceae) est en adéquation complète avec les derniers témoignages polliniques recensés dans le golfe du Lion et en Adriatique centrale. Au contraire, celle de Pterocarya (Juglandaceae) est sujette à discussion. La distribution très disjointe de Cedrus (Pinaceae) est le résultat des vicissitudes climatiques sur le continent eurasiatique où, semble-t-il, trois événements géodynamiques ont permis sa survie (figure 10) : le soulèvement du Tibet pendant l'orogenèse himalayenne pour C. deodara, l'extrusion de la péninsule anatolienne pour $C$. libani, la dessiccation momentanée de la Méditerranée pour $C$. atlantica. L'extinction du Cèdre sur le continent nordaméricain demeure par contre très insuffisamment documentée et sans explication si ce n'est à cause des péjorations climatiques qui, pourtant, n'en ont pas éliminé Tsuga.

\section{Introduction}

This paper summarizes 37 years of collaboration with Pierre Quézel, former Professor at Aix-Marseilles University and famous specialist of ecology and biogeography of plants in the Mediterranean region (Médail, 2018), marked by several important papers aiming to decipher the onset of the modern Mediterranean flora, vegetation and climate on the basis of pollen records from the last 23 million years (Ma). Resulting from a new approach to Neogene palynology (Suc \& Bessedik, 1981), this synthesis considers more than 220 localities (figure 1) studied within the frame of 29 analytic major analytical works (10 Master theses; $15 \mathrm{PhD}$ theses; 4 State theses) (table 1; see also: Suc et al., 1999; Suc \& Popescu, 2005; JiménezMoreno \& Suc, 2007; Jiménez-Moreno et al., 2007; Popescu et al., 2010; Suc et al., 2010). Collected data has increased in recent years (e.g.: Jiménez-Moreno et al., 2009, 2013, 2015; Bertini, 2010; Combourieu-Nebout et al., 2015; Suc \& Popescu, studies in progress), making this school unquestionably the most suitable one for past reconstructions of the Neogene Mediterranean flora and vegetation. In addition, most of the data are quantified climatically by applying a method based on

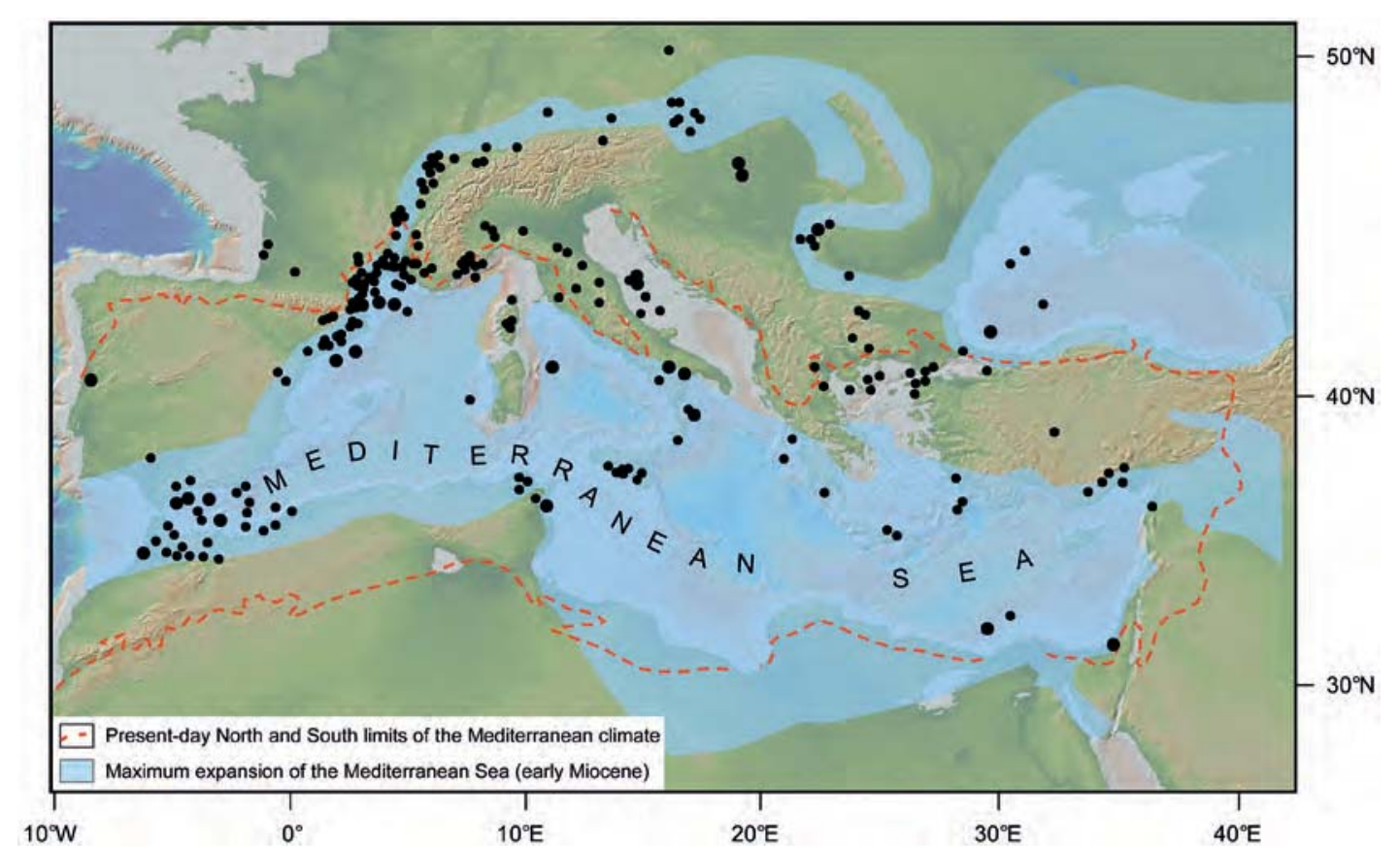

Figure 1 - Geographic location of the studied Late Cenozoic pollen floras in the Mediterranean region considered in this paper.

Larger dots correspond to long pollen records.

The present-day limits of the Mediterranean climate are from Quézel \& Médail (2003).

The maximum expansion of the Mediterranean Sea (early Miocene) is from Meulenkamp \& Sissingh (2003).

All the maps are elaborated using GeoMapApp from Ryan et al. (2009). 
present-day pollen records and plant distribution (Fauquette et al., 1998a \& b, 2007). This paper does not aim to provide a complete review of all the available pollen data from the Late Cenozoic in the Mediterranean region. The displayed pollen records are all characterized by the same level of quality in identifying pollen grains and can be statistically analyzed as we have all the detailed counts. In particular, the Pleistocene and Holocene times are represented by only few (often long) records, covering the last 2.6 Ma. Overall, these data are the results of our intense collaboration with Pierre Quézel that justifies this synthesis in the issue dedicated to his memory.

After a recap of the main aspects of the methods used, we synthesize the most significant results at the whole Mediterranean scale with focus on (1) floral - vegetation changes, (2) quantified climatic evolution, and (3) biogeographical history of selected taxa.

\section{Methods}

Following Zagwijn (1960) and Pons (1964), the most impressive palaeoecological progress reached in the 1970's lies in the botanical identification of fossil pollen grains, which was possible due to detailed morphological analyses and accurate comparisons with modern taxa. In this way, identifications are usually done at the genus level for tree pollen with some examples at the species level, and at the family level for herb pollen except for some genera and species. This successful botanical approach severely contrasts with the previously used artificial nomenclature, which unfortunately is still considered by some palynologists for the Neogene (e.g. Bruch, 2004; Barron et al., 2016). This artificial nomenclature supports the myth of a superficial morphological analysis of the pollen while the botanical approach is based on accurately documented pollen morphology. In addition, the artificial nomenclature keeps alive the faith in species level identification by using a pseudo-binomial such as Subtriporopollenites simplex (Pot.) Th. \& Pf. or Tetracolporopollenites manifestus (Pot.) Th. \& Pf. This method evokes only one simple morphological character (triporate pollen and tetracolporate pollen, respectively) so far from the complex morphological description of any one pollen grain. Sometimes, the used binomial directly recalls a botanical genus, for example Caryapollenites simplex Pot. or Sciadopityspollenites tuberculatus (Zakl.) W.Kr.: why attach the pollenites suffix plus useless pseudo-species name as the pollen is easily identifiable at the genus level and only at this level? In fact, the out-dated artificial nomenclature denotes an inadequate expertise in pollen morphology, especially the non-practice of the effective L.O. analysis of Erdtman (1952) and shows a lack of experience in pollen grains from the various modern vegetation realms of the Earth.

More than 260 axa (determined to family and/ or genus and/or sometimes species levels) are now identified in the Late Cenozoic (i.e. the last $23 \mathrm{Ma}$ ) of the Mediterranean region are listed in table 2 with respect to their epochs of occurrence (Miocene, Pliocene or Quaternary) and their major chronostratigraphic subdivisions. Thanks to this unrivalled effort, 74 taxa have been indicated for the first time in the Mediterranean Late Cenozoic (table 2). Any pollen analyst wishing to develop a robust botanical approach can find a complete documentation on fossil and modern pollen descriptions and photographs in the theses mentioned in table 1 and following papers (Lobreau-Callen \& Suc, 1972; Suc, 1973, 1974, 1976a, 1976b, 1978a, 1978b; Naud \& Suc, 1975; Julià Bruguès \& Suc, 1980; Cravatte \& Suc, 1981; Bessedik, 1983; Suc et al., 1986; Bessais \& Cravatte, 1988; Zheng, 1990; Suc et al., 2004; Jiménez-Moreno \& Suc, 2007; Popescu et al., 2010; Biltekin et al., 2015).

For building synthetic pollen diagrams, taxa are mostly grouped according to a global "ecological niche" corresponding to the mean annual temperature (MAT) under which their present-day representatives are living (Nix, 1982) plus other climatic (mainly linked to xericity) or edaphic considerations, and their status that can be deduced from variations in their pollen records over time (table 2):

- Megatherm plants inhabiting equatorial and tropical forests: MAT $>24^{\circ} \mathrm{C}$;

- Mega-mesotherm plants living in subtropical forests: $24^{\circ} \mathrm{C}>\mathrm{MAT}>20^{\circ} \mathrm{C}$;

- Mesotherm plants corresponding to warmtemperate forests: $20^{\circ} \mathrm{C}>\mathrm{MAT}>14^{\circ} \mathrm{C}$;

- Meso-microtherm plants growing in cooltemperate forests, including Cathaya, a relictuous altitudinal conifer in subtropical China: $14^{\circ} \mathrm{C}>\mathrm{MAT}>12^{\circ} \mathrm{C}$;

- Microtherm plants constituting the boreal coniferous forests: MAT $<12^{\circ} \mathrm{C}$; 
Table 1 - Listing of the 29 pollen analytic theses that contributed to establish the Mediterranean flora during the Late Cenozoic. Authors of Master theses are underlined, those of PhD theses are in normal characters, those of State theses are in bold characters.

\begin{tabular}{|c|c|c|c|c|}
\hline $\begin{array}{l}\text { Thesis } \\
N^{\circ}\end{array}$ & Name & Year & Title & University \\
\hline 1 & Acherki N. & 1997 & $\begin{array}{l}\text { Analyse palynologique de quatre carottes du golfe du Lion. Application à la } \\
\text { restitution de la végétation et du climat du midi de la France pendant le dernier cycle } \\
\text { climatique et à la stratigraphie marine }\end{array}$ & Montpellier II, France \\
\hline 2 & $\begin{array}{l}\text { Bachiri } \\
\text { Taoufiq } \mathbf{N} \text {. }\end{array}$ & 2000 & $\begin{array}{l}\text { Les environnements marins et continentaux du corridor rifain au Miocène supérieur } \\
\text { d'après la palynologie }\end{array}$ & Casablanca, Morocco \\
\hline 3 & Beaudouin C. & 2003 & $\begin{array}{l}\text { Effets du dernier cycle climatique sur la végétation de la basse vallée du Rhône et sur } \\
\text { la sédimentation de la plate-forme du golfe du Lion d'après la palynologie }\end{array}$ & Lyon I, France \\
\hline 4 & Bertini A. & 1992 & $\begin{array}{l}\text { Palinologia ed aspetti ambientali del versante adriatico dell'Appennino centro- } \\
\text { settentrionale durante il Messiniano e lo Zancleano }\end{array}$ & Florence, Italy \\
\hline 5 & Bessais E. & 1984 & Étude palynologique du Pliocène du sondage Tarragone E2 & Montpellier II, France \\
\hline 6 & Bessedik M. & 1985 & $\begin{array}{l}\text { Reconstitution des environnements miocènes des régions nord-ouest } \\
\text { méditerranéennes à partir de la palynologie }\end{array}$ & Montpellier II, France \\
\hline 7 & Biltekin D. & 2006 & $\begin{array}{l}\text { Vegetation and climate of North Anatolian and North Aegean region since } 7 \mathrm{Ma} \\
\text { according to pollen analysis }\end{array}$ & $\begin{array}{l}\text { Lyon I, France } \\
\text { Istanbul, Turkey }\end{array}$ \\
\hline 8 & Brenac P. & 1983 & $\begin{array}{l}\text { Analyse pollinique des dépôts lacustres de Camerota (Plio-Pléistocène inférieur) - } \\
\text { Italie méridionale }\end{array}$ & Montpellier II, France \\
\hline 9 & Chikhi $\mathrm{H}$. & 1992 & $\begin{array}{l}\text { Palynoflore du Messinien infra-évaporitique de la série marno-diatomitique de } \\
\text { Sahaouria (Beni-Chougrane) et de Chabet Bou Seter (Tessala), bassin du Chelif, } \\
\text { Algérie }\end{array}$ & Oran, Algeria \\
\hline 10 & $\begin{array}{l}\text { Combourieu- } \\
\text { Nebout N. }\end{array}$ & 1987 & $\begin{array}{l}\text { Les premiers cycles glaciaires-interglaciaires en région méditerranéenne d'après } \\
\text { I'analyse palynologique de la série plio-pléistocène de Crotone (Italie méridionale) }\end{array}$ & Montpellier II, France \\
\hline 11 & Cuinet J. & 2007 & $\begin{array}{l}\text { Végétation, climat, incendies dans le Bas-Rhône depuis } 12000 \text { ans. Étude } \\
\text { palynologique de la carotte SF (Cacharel) }\end{array}$ & Lyon I, France \\
\hline 12 & Dalibard M. & 2007 & $\begin{array}{l}\text { Végétation et climat du dernier cycle climatique en Italie centrale. } \\
\text { Analyse pollinique de la carotte PRAD1-2 (mer Adriatique) }\end{array}$ & Lyon I, France \\
\hline 13 & Diniz F. & 1984 & $\begin{array}{l}\text { Apports de la palynologie à la connaissance du Pliocène portugais. Rio Maior : un } \\
\text { bassin de référence pour l'histoire de la flore, de la végétation et du climat de la } \\
\text { façade atlantique de l'Europe méridionale }\end{array}$ & Montpellier II, France \\
\hline 14 & Drivaliari A. & 1986 & $\begin{array}{l}\text { Sédimentation pollinique dans le paléogolfe de l'Orb : corrélations avec la végétation } \\
\text { et le climat }\end{array}$ & Montpellier II, France \\
\hline 15 & Drivaliari A. & 1993 & $\begin{array}{l}\text { Images polliniques et paléoenvironnements au Néogène supérieur en Méditerranée } \\
\text { orientale. Aspects climatiques et paléogéographiques d'un transect latitudinal (de la } \\
\text { Roumanie au delta du Nil) }\end{array}$ & Montpellier II, France \\
\hline 16 & Dubois J.-M. & 2001 & $\begin{array}{l}\text { Cycles climatiques et paramètres orbitaux vers } 1 \mathrm{Ma} \text {. Étude de la couoe de Monte } \\
\text { San Giorgio (Caltagirone, Sicile) : palynologie, isotopes stables, calcimétrie }\end{array}$ & Lyon I, France \\
\hline 17 & $\begin{array}{l}\text { Jiménez- } \\
\text { Moreno G. }\end{array}$ & 2005 & $\begin{array}{l}\text { Utilización del análisis polínico para la reconstrucción de la vegetación, clima y } \\
\text { estimación de paleoaltitudes a lo largo de arco alpino europeo durante el Mioceno } \\
(21-8 \mathrm{Ma})\end{array}$ & $\begin{array}{l}\text { Granada, Spain } \\
\text { Lyon I, France }\end{array}$ \\
\hline 18 & Joannin S. & 2007 & $\begin{array}{l}\text { Changements climatiques en Méditerranée à la transition Pléistocène inférieur- } \\
\text { moyen : pollens, isotopes stables et cyclostratigraphie }\end{array}$ & Lyon I, France \\
\hline 19 & Leroy S. & 1990 & $\begin{array}{l}\text { Paléoclimats plio-pléistocènes en Catalogne et Languedoc d'après la palynologie de } \\
\text { formations lacustres }\end{array}$ & $\begin{array}{l}\text { (Roman) Louvain, } \\
\text { Belgium }\end{array}$ \\
\hline 20 & Mrioo Z. & 2010 & $\begin{array}{l}\text { La végétation et le climat du golfe d'Hammamet (Tunisie) du Miocène terminal au } \\
\text { Pliocène supérieur d'après l'analyse pollinique }\end{array}$ & Casablanca, Morocco \\
\hline 21 & Popescu S.-M. & 2001 & $\begin{array}{l}\text { Végétation, climat et cyclostratigraphie en Paratéthys centrale au Miocène supérieur } \\
\text { et au Pliocène inférieur d'après la palynologie }\end{array}$ & Lyon I, France \\
\hline 22 & Russo Ermoli E. & 1995 & $\begin{array}{l}\text { Analyse pollinique des dépôts lacustres pléistocènes du Vallo di Diano (Campanie, } \\
\text { Italie) : cyclicités et quantification climatiques }\end{array}$ & Liège, Belgium \\
\hline 23 & Sachse M. & 1997 & $\begin{array}{l}\text { Die Makrilia-flora (Kreta, Griechenland) - Ein beitrag zur Neogenen klima- und } \\
\text { vegetationsgeschichte des Östlichen Mittelmeergebietes }\end{array}$ & Zurich, Switzerland \\
\hline 24 & $\underline{\text { Safra A. }}$ & 2007 & Flore et climat de la Tunisie nord-orientale au Messinien et Pliocène & Tunis, Tunisia \\
\hline 25 & Suballyova D. & 1997 & $\begin{array}{l}\text { Expression palynologique en Méditerranée des cycles glaciaires-interglaciaires } \\
\text { arctiques anciens et cyclostratigraphie }\end{array}$ & Lyon I, France \\
\hline 26 & Suc J.-P. & 1980 & $\begin{array}{l}\text { Contribution à la connaissance du Pliocène et du Pléistocène supérieur des régions } \\
\text { méditerranéennes d'Europe occidentale par l'analyse palynologique des dépôts du } \\
\text { Languedoc-Roussillon (sud de la France) et de la Catalogne (nord-est de l'Espagne) }\end{array}$ & Montpellier II, France \\
\hline 27 & $\underline{\text { Tinacci } D .}$ & 2005 & $\begin{array}{l}\text { La registrazione pollinica in un sistema prodeltaico come strumento per la } \\
\text { riconstruzione paleoambientale della bassa valle del Rodano durante I'Olocene }\end{array}$ & Florence, Italy \\
\hline 28 & Warny S. & 1999 & $\begin{array}{l}\text { Mio-Pliocene palynology of the Gibraltar Arc: A new perspective on the Messinian } \\
\text { Salinity Crisis }\end{array}$ & $\begin{array}{l}\text { (Roman) Louvain, } \\
\text { Belgium }\end{array}$ \\
\hline 29 & Zheng Z. & 1986 & $\begin{array}{l}\text { Contribution palynologique à la connaissance du Néogène du Sud-Est français et de } \\
\text { Ligurie }\end{array}$ & Montpellier II, France \\
\hline
\end{tabular}


Table 2 - Listing of taxa (at the family, genus and sometimes species level) identified at the Mediterranean scale according to pollen grains from the Late Cenozoic deposits, distributed according to the main chronostratigraphic subdivisions. Taxa identified for the first time in the Mediterranean Late Cenozoic are underlined in grey.

\begin{tabular}{|c|c|c|c|c|c|c|c|c|c|c|c|}
\hline \multirow{2}{*}{ Family } & \multirow[t]{2}{*}{ Genus } & \multirow[t]{2}{*}{ Species } & \multicolumn{3}{|c|}{ Miocene } & \multicolumn{2}{|c|}{ Pliocene } & \multicolumn{4}{|c|}{ Quaternary } \\
\hline & & & $\frac{\lambda}{\frac{1}{\pi}}$ & $\frac{\frac{\partial}{\bar{O}}}{\frac{0}{\varepsilon}}$ & 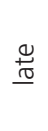 & $\frac{\lambda}{\frac{\pi}{\pi}}$ & 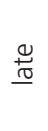 & 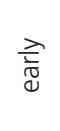 & $\frac{\frac{\partial}{\overline{0}}}{\frac{\partial}{\varepsilon}}$ & $\underset{ \pm}{\stackrel{ \pm}{0}}$ & 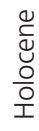 \\
\hline \multicolumn{12}{|c|}{ Megatherm plants: } \\
\hline \multirow[t]{3}{*}{ Acanthaceae } & & & + & + & + & + & + & + & & & \\
\hline & Avicennia & & + & + & + & + & & + & & & \\
\hline & Blepharis & & & & & & & + & & & \\
\hline Bombacaceae & Bombax & & + & + & + & + & & + & & & \\
\hline Buxaceae & Buxus & bahamensis-type & + & + & + & + & & & & & \\
\hline Cucurbitaceae & & & & & & + & & & & & \\
\hline \multirow[t]{7}{*}{ Euphorbiaceae } & & & + & + & + & + & + & & & & \\
\hline & Alchornea & & + & + & + & + & + & & & & \\
\hline & Amanoa & & & & + & + & & & & & \\
\hline & Claoxylon-type & & + & + & & & & & & & \\
\hline & Croton & & + & + & + & + & + & + & & & \\
\hline & Jatropha & & + & + & & & & & & & \\
\hline & Phyllanthus-type & & & + & + & & & & & & \\
\hline \multirow[t]{2}{*}{$\begin{array}{l}\text { Leguminosae } \\
\text { Caesalpinioideae }\end{array}$} & & & + & + & + & & & & & & \\
\hline & Sindora & & & + & + & + & & & & & \\
\hline \multirow[t]{3}{*}{ Mimosoideae } & & & + & + & + & + & & & & & \\
\hline & Acacia & & + & + & & & & & & & \\
\hline & Prosopis & cf. farcta & + & + & + & + & + & + & & & \\
\hline \multirow[t]{2}{*}{ Hamamelidaceae } & Altinghia & & & & + & & & & & & \\
\hline & Fothergilla & & + & + & + & + & & & & & \\
\hline \multirow[t]{2}{*}{ Icacinaceae } & & & + & + & + & + & & & & & \\
\hline & Mappianthus & & + & + & & & & & & & \\
\hline \multirow[t]{2}{*}{ Malpighiaceae } & & & + & + & + & & & + & & & \\
\hline & Malpighia & & + & + & & & & & & & \\
\hline Malvaceae & Grewia-Corchorus & & + & + & + & & & & & & \\
\hline Melastomataceae & & & + & + & + & & & & & & \\
\hline Meliaceae & & & + & + & + & + & & & & & \\
\hline Passifloraceae & & & + & + & + & + & + & & & & \\
\hline \multirow[t]{2}{*}{ Rubiaceae } & & & + & + & + & & & & & & \\
\hline & Canthium-type & & & & + & & + & & & & \\
\hline Rutaceae & & & + & + & + & + & & & & & \\
\hline \multirow[t]{2}{*}{ Simaroubaceae } & $\begin{array}{l}\text { (Pentapollenites: } \\
\text { fossil genus) }\end{array}$ & & + & + & + & & & & & & \\
\hline & Picrasma & & + & + & & & & & & & \\
\hline \multicolumn{12}{|c|}{ Mega-mesotherm plants: } \\
\hline \multirow[t]{4}{*}{ Asparagaceae } & & & & + & + & + & & & & & \\
\hline & Cordyline & & + & + & & & & & & & \\
\hline & cf. Dracaena & & & & & + & & & & & \\
\hline & Nolina & & & & + & + & & + & & & \\
\hline Alangiaceae & Alangium & & & + & & + & & & & & \\
\hline Anacardiaceae & & & + & + & + & + & + & + & + & & \\
\hline
\end{tabular}




\begin{tabular}{|c|c|c|c|c|c|c|c|c|c|c|c|}
\hline \multirow[t]{2}{*}{ Family } & \multirow[t]{2}{*}{ Genus } & \multirow[t]{2}{*}{ Species } & \multicolumn{3}{|c|}{ Miocene } & \multicolumn{2}{|c|}{ Pliocene } & \multicolumn{4}{|c|}{ Quaternary } \\
\hline & & & 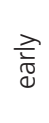 & $\frac{\frac{\varrho}{\partial}}{\frac{O}{E}}$ & 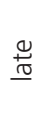 & 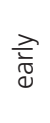 & 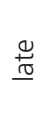 & $\frac{\lambda}{\frac{1}{\mathbb{C}}}$ & $\frac{\frac{\varrho}{\partial}}{\frac{O}{\varepsilon}}$ & 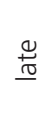 & 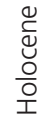 \\
\hline Aquifoliaceae & Ilex & floribunda-type & & & + & + & & + & & & \\
\hline Araliaceae & & & + & & + & + & + & + & + & & \\
\hline Arecaceae & & & + & + & + & + & + & + & + & & \\
\hline Berberidaceae & & & + & & + & + & & & & & \\
\hline Bignoniaceae & & & + & & & & & & & & \\
\hline \multirow[t]{3}{*}{ Celastraceae } & & & + & + & + & + & + & + & & & \\
\hline & Microtropis & fallax & + & + & + & + & + & + & & & \\
\hline & & cf. fokienensis & & & + & + & & & & & \\
\hline Chloranthaceae & & & + & + & & & & & & & \\
\hline Convolvulaceae & Ipomoea & & + & + & & & & & & & \\
\hline \multirow{4}{*}{$\begin{array}{l}\text { Coriaraceae } \\
\text { Cornaceae }\end{array}$} & Coriaria & & & & + & & & + & + & & \\
\hline & & & + & & & & & & & & \\
\hline & Cornus & & + & + & & + & & + & + & & + \\
\hline & Nyssa & cf. sinensis & + & + & & + & + & + & & & \\
\hline \multirow[t]{3}{*}{ Cupressaceae } & $\begin{array}{l}\text { Unidentified } \\
\text { 'taxodioid' pollen }\end{array}$ & & + & + & + & + & + & + & & & \\
\hline & Sequoia-type & & + & + & + & + & + & + & + & & \\
\hline & $\begin{array}{l}\text { Taxodium-type } \\
\text { (Glyptostrobus) }\end{array}$ & & + & + & + & + & + & + & + & + & + \\
\hline Cyrillaceae - Clethraceae & & & + & + & + & + & + & + & & & \\
\hline \multirow[t]{2}{*}{ Euphorbiaceae } & Mallotus & & & + & + & & & & & & \\
\hline & Ricinus & & + & + & + & + & + & + & & & \\
\hline Gingkoaceae & Gingko & & & + & + & + & + & & & & \\
\hline \multirow[t]{12}{*}{ Hamamelidaceae } & & & + & + & + & + & + & + & + & & \\
\hline & Corylopsis & & + & + & + & & & & & & \\
\hline & Dicoryphe-type & & & & + & & & & & & \\
\hline & Disanthus & & + & & & & & & & & \\
\hline & Distylium & cf. chinensis & + & + & + & + & + & + & & & \\
\hline & Embolanthera & & + & & + & + & + & & & & \\
\hline & Eustigma & & + & + & & & & & & & \\
\hline & Exbucklandia & & + & & + & & & & & & \\
\hline & Hamamelis & cf. mollis & + & + & + & + & + & + & & & \\
\hline & Loropetalum & & + & & + & + & & + & & & \\
\hline & Rhodoleia & & + & + & + & & & & & & \\
\hline & cf. Trichocladus & & + & + & & & & & & & \\
\hline Iteaceae & Itea & & & & + & & & & & & \\
\hline \multirow[t]{2}{*}{ Juglandaceae } & Engelhardia & & + & + & + & + & + & + & + & & \\
\hline & Platycarya & & + & + & + & + & + & + & & & \\
\hline Loranthaceae & & & + & + & + & + & + & + & & & \\
\hline Lythraceae & Decodon & & & & + & + & + & & & & \\
\hline \multirow[t]{2}{*}{ Magnoliaceae } & & & & & + & + & & + & & & \\
\hline & Liriodendron & & & & + & + & & & & & \\
\hline Malvaceae & Craigia & & & & + & + & & + & & & \\
\hline $\begin{array}{l}\text { Menispermaceae tribe } \\
\text { Cocculae }\end{array}$ & & & + & + & + & + & + & + & & & \\
\hline Myricaceae & Myrica & & + & + & + & + & + & + & + & + & + \\
\hline Poaceae & cf. Bambusa & & + & & + & & & & & & \\
\hline Rhoipteleaceae & Rhoiptelea & & + & + & + & + & + & + & & & \\
\hline \multirow[t]{2}{*}{ Rubiaceae } & Mussaenda-type & & + & + & + & + & & & & & \\
\hline & Uncaria-type & & + & & & + & & & & & \\
\hline \multirow[t]{2}{*}{ Sapindaceae } & & & + & + & + & + & & + & & & \\
\hline & Dodonaea & & + & + & + & & & & & & \\
\hline
\end{tabular}




\begin{tabular}{|c|c|c|c|c|c|c|c|c|c|c|c|}
\hline \multirow[t]{2}{*}{ Family } & \multirow[t]{2}{*}{ Genus } & \multirow[t]{2}{*}{ Species } & \multicolumn{3}{|c|}{ Miocene } & \multicolumn{2}{|c|}{ Pliocene } & \multicolumn{4}{|c|}{ Quaternary } \\
\hline & & & $\frac{\lambda}{\sqrt{\pi}}$ & $\frac{\frac{\varrho}{\overline{0}}}{\frac{0}{\varepsilon}}$ & 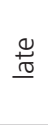 & $\frac{2}{\sqrt{\pi}}$ & 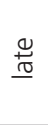 & $\frac{\lambda}{\frac{\pi}{\pi}}$ & $\frac{\frac{\omega}{\partial}}{\frac{\partial}{\varepsilon}}$ & $\underset{\mathbb{0}}{\stackrel{0}{0}}$ & $\begin{array}{l}\text { 뤄 } \\
\text { 응 } \\
\text { 오 }\end{array}$ \\
\hline Sapotaceae & & & + & + & + & + & + & + & & & \\
\hline \multirow[t]{2}{*}{ Symplocaceae } & Symplocos & & + & + & + & + & + & + & + & & \\
\hline & & cf. paniculata & + & + & & + & + & & & & \\
\hline Sciadopityaceae & Sciadopitys & & + & + & + & + & + & + & + & & \\
\hline Theaceae & & & + & + & + & & & & & & \\
\hline Vitaceae & Leea & & + & + & + & + & + & + & & & \\
\hline \multicolumn{12}{|c|}{ Mesotherm plants: } \\
\hline Aceraceae & Acer & & + & + & + & + & + & + & + & + & + \\
\hline Anacardiaceae & Rhus & & + & + & + & + & & + & & & + \\
\hline Aquifoliaceae & Ilex & & + & + & + & + & + & + & + & & + \\
\hline Araliaceae & Hedera & cf. helix & + & + & + & + & + & + & + & + & + \\
\hline \multirow[t]{7}{*}{ Betulaceae } & Alnus & & + & + & + & + & + & + & + & + & + \\
\hline & Betula & & + & + & + & + & + & + & + & + & + \\
\hline & Carpinus & & + & + & + & + & + & + & + & + & + \\
\hline & & cf. betulus & + & & + & + & + & + & + & + & + \\
\hline & & cf. orientalis & + & + & + & + & + & + & + & + & + \\
\hline & Corylus & & + & + & + & + & + & + & + & + & + \\
\hline & Ostrya & & + & + & + & + & + & + & + & & + \\
\hline Buxaceae & Buxus & cf. sempervirens & + & + & + & + & + & + & + & + & + \\
\hline Cannabaceae & Celtis & & + & + & + & + & + & + & + & + & + \\
\hline \multirow[t]{3}{*}{ Caprifoliaceae } & Lonicera & & + & + & + & + & & + & + & & + \\
\hline & Sambucus & & & & + & + & & + & + & + & + \\
\hline & Viburnum & & + & + & + & + & + & + & + & + & + \\
\hline Celastraceae & Evonymus & & & & + & + & & + & + & + & + \\
\hline Cornaceae & Nyssa & cf. aquatica & & & + & + & + & + & + & & \\
\hline Elaeagnaceae & Elaeagnus & & + & + & + & & & + & + & & + \\
\hline Ericaceae & & & + & + & + & + & + & + & + & + & + \\
\hline Eucommiaceae & Eucommia & & + & + & + & + & + & + & + & + & \\
\hline \multirow[t]{2}{*}{ Fagaceae } & $\begin{array}{l}\text { Castanea-type } \\
\text { (Castanopsis?) }\end{array}$ & & + & + & + & + & + & + & + & + & + \\
\hline & $\begin{array}{l}\text { Quercus } \\
\text { (deciduous) }\end{array}$ & & + & + & + & + & + & + & + & + & + \\
\hline \multirow[t]{3}{*}{ Hamamelidaceae } & Liquidambar & & + & + & + & + & + & + & + & + & \\
\hline & Parrotia & cf. persica & + & + & + & + & + & + & + & + & \\
\hline & Parrotiopsis & cf. jacquemontiana & + & & + & + & + & + & & & \\
\hline \multirow[t]{4}{*}{ Juglandaceae } & Carya & & + & + & + & + & + & + & + & + & \\
\hline & Juglans & & + & + & + & + & + & + & + & + & + \\
\hline & & cf. cathayensis & + & + & + & + & + & + & & & \\
\hline & Pterocarya & & + & + & + & + & + & + & + & + & + \\
\hline Malvaceae & Tilia & & + & + & + & + & + & + & + & + & + \\
\hline \multirow[t]{2}{*}{ Oleaceae } & Fraxinus & & + & + & + & + & + & + & + & + & + \\
\hline & Ligustrum & & + & + & + & + & + & + & + & + & + \\
\hline Platanaceae & Platanus & & + & + & + & + & + & + & + & + & + \\
\hline \multirow[t]{2}{*}{ Salicaceae } & Populus & & + & & + & + & + & + & + & + & + \\
\hline & Salix & & + & + & + & + & + & + & + & + & + \\
\hline Santalaceae & Arceuthobium & & + & & + & & & & & & \\
\hline
\end{tabular}




\begin{tabular}{|c|c|c|c|c|c|c|c|c|c|c|c|}
\hline \multirow[t]{2}{*}{ Family } & \multirow[t]{2}{*}{ Genus } & \multirow[t]{2}{*}{ Species } & \multicolumn{3}{|c|}{ Miocene } & \multicolumn{2}{|c|}{ Pliocene } & \multicolumn{4}{|c|}{ Quaternary } \\
\hline & & & $\frac{\lambda}{\frac{1}{\mathbb{d}}}$ & $\frac{\frac{\partial}{0}}{\frac{O}{E}}$ & 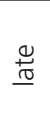 & 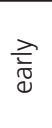 & $\underset{ \pm}{\stackrel{\oplus}{0}}$ & $\frac{\mathbb{2}}{\stackrel{\mathbb{E}}{\mathbb{d}}}$ & 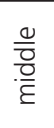 & $\stackrel{\oplus}{\stackrel{ \pm}{0}}$ & 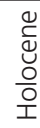 \\
\hline Sapindaceae & Aesculus & \multirow[t]{6}{*}{ cf. hippocastanum } & + & & & + & & & & + & + \\
\hline Tamaricaceae & Tamarix & & + & + & + & + & + & + & + & + & + \\
\hline Taxaceae & & & + & & + & + & + & + & + & & + \\
\hline Ulmaceae & Ulmus & & + & + & + & + & + & + & + & + & + \\
\hline \multirow{5}{*}{ Vitaceae } & Zelkova & & + & + & + & + & + & + & + & + & + \\
\hline & Cissus & & + & + & + & & & & & & \\
\hline & Parthenocissus & cf. henryana & + & + & + & + & + & + & + & & \\
\hline & & cf. quinquefolia & & & & + & & & + & + & \\
\hline & Vitis & & + & + & + & + & + & + & + & + & + \\
\hline \multicolumn{12}{|c|}{ Meso-microtherm plants: } \\
\hline \multirow{5}{*}{$\begin{array}{l}\text { Fagaceae } \\
\text { Pinaceae }\end{array}$} & Fagus & & + & + & + & + & + & + & + & + & + \\
\hline & Cathaya & & + & + & + & + & + & + & + & + & \\
\hline & Cedrus & & + & + & + & + & + & + & + & + & + \\
\hline & Keteleeria & & & + & + & + & + & + & & & \\
\hline & Tsuga & & + & + & + & + & + & + & + & + & . \\
\hline \multicolumn{12}{|l|}{ Microtherm plants: } \\
\hline \multirow[t]{2}{*}{ Pinaceae } & Abies & & + & + & + & + & + & + & + & + & + \\
\hline & Picea & & + & + & + & + & + & + & + & + & + \\
\hline Cupressaceae & $\begin{array}{l}\text { Cupressus- } \\
\text { Juniperus pollen- } \\
\text { type }\end{array}$ & & + & + & + & + & + & + & + & + & + \\
\hline \multicolumn{12}{|l|}{ Aquatic plants: } \\
\hline$?$ & $\begin{array}{l}\text { Aglaoreidia: fossil } \\
\text { genus }\end{array}$ & & + & & & & & & & & \\
\hline Alismataceae & Alisma & & & & + & + & & + & + & + & + \\
\hline Gunneraceae & Gunnera & & & + & & & & & & & \\
\hline Haloragaceae & Myriophyllum & & + & & + & + & + & + & + & + & + \\
\hline Lentibulariaceae & Utricularia & & & & & + & & & & & \\
\hline Lythraceae & & & & & + & + & & + & + & & + \\
\hline & Trapa & & + & & & + & & & & & \\
\hline Menyanthaceae & & & & & & & & & + & & \\
\hline Nymphaeaceae & & & + & + & + & + & + & + & + & & + \\
\hline Onagraceae & & & + & + & + & + & + & + & + & + & + \\
\hline Potamogetonaceae & Potamogeton & & + & + & + & + & + & + & + & + & + \\
\hline \multirow[t]{2}{*}{ Restionaceae } & & & + & + & + & + & + & + & & & \\
\hline & Restio & & + & + & + & + & & & & & \\
\hline Rubiaceae & Cephalanthus & & & & + & + & + & + & & & \\
\hline Ruppiaceae & Ruppia & & + & + & & & & & & & + \\
\hline \multirow[t]{2}{*}{ Typhaceae } & Sparganium & & + & + & + & + & + & + & + & + & + \\
\hline & Typha & & + & + & + & + & + & + & + & + & + \\
\hline \multicolumn{12}{|c|}{ Mediterranean sclerophyllous plants: } \\
\hline \multirow[t]{2}{*}{ Anacardiaceae } & Pistacia & \multirow{4}{*}{ cf. cotinus } & + & + & + & + & + & + & + & + & + \\
\hline & Rhus & & + & & + & + & + & + & + & & + \\
\hline Apocynaceae & Nerium & & + & & + & + & + & + & + & & \\
\hline Cistaceae & Cistus & & + & + & + & + & + & + & + & + & + \\
\hline & & cf. monspeliensis & & & & + & + & + & + & & \\
\hline & & cf. salvifolius & & & + & + & & & + & & + \\
\hline Ericaceae & Erica & cf. arborea & & & & + & + & + & + & & + \\
\hline $\begin{array}{l}\text { Fabaceae } \\
\text { Caesalpinioideae }\end{array}$ & Ceratonia & & + & + & + & + & & + & + & + & + \\
\hline Fagaceae & Quercus & ilex-type & + & + & + & + & + & + & + & + & + \\
\hline Lamiaceae & Phlomis & cf. fruticosa & + & & + & + & + & + & + & + & + \\
\hline
\end{tabular}




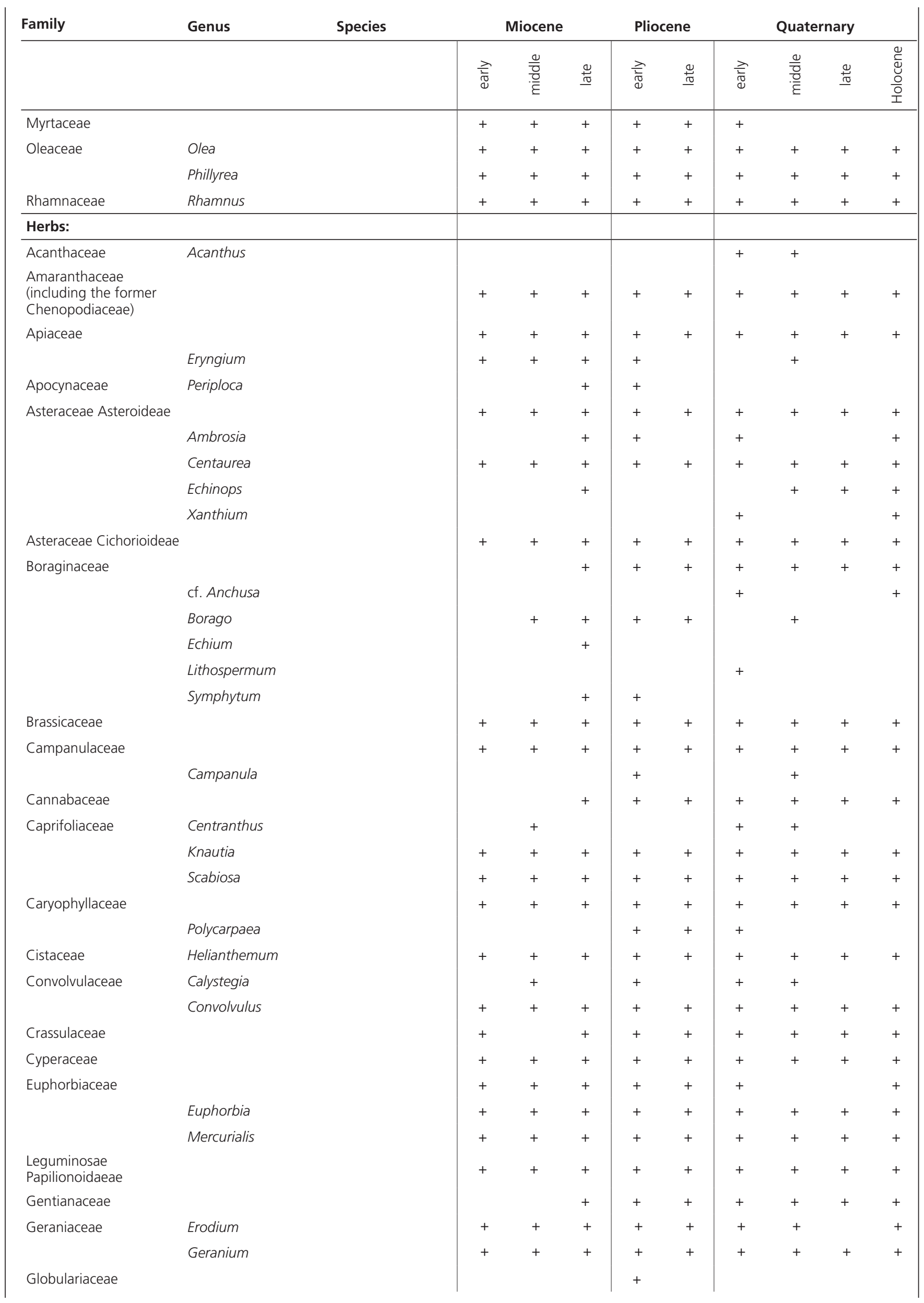




\begin{tabular}{|c|c|c|c|c|c|c|c|c|c|c|c|}
\hline \multirow[t]{2}{*}{ Family } & \multirow[t]{2}{*}{ Genus } & \multirow[t]{2}{*}{ Species } & \multicolumn{3}{|c|}{ Miocene } & \multicolumn{2}{|c|}{ Pliocene } & \multicolumn{4}{|c|}{ Quaternary } \\
\hline & & & $\frac{\lambda}{\frac{\lambda}{\pi}}$ & $\frac{\frac{0}{\bar{g}}}{\frac{0}{\varepsilon}}$ & $\stackrel{\oplus}{ \pm}$ & $\frac{\substack{\frac{1}{\pi} \\
d}}{2}$ & 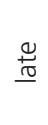 & $\frac{\substack{\frac{\pi}{\pi} \\
d}}{2}$ & $\frac{\frac{0}{D}}{\frac{0}{E}}$ & $\underset{\stackrel{ \pm}{ \pm}}{\stackrel{\Xi}{0}}$ & $\begin{array}{l}\stackrel{\square}{\Phi} \\
\text { 응 } \\
\text { 오 }\end{array}$ \\
\hline $\begin{array}{l}\text { Grossulariaceae } \\
\text { Iridaceae }\end{array}$ & Ribes & & + & & + & + & & + & + & + & + \\
\hline Lamiaceae & & & + & + & + & + & + & + & + & + & + \\
\hline Liliaceae & Colchicum & & + & + & + & + & + & + & $\begin{array}{l}+ \\
+\end{array}$ & + & $\begin{array}{l}+ \\
+\end{array}$ \\
\hline Linaceae & Linum & usitatissimum & + & + & + & + & + & + & + & + & + \\
\hline Malvaceae & & & + & + & + & + & + & + & & + & + \\
\hline Papaveraceae & & & + & & + & + & & + & + & + & + \\
\hline Plantaginaceae & Plantago & & + & + & + & + & + & + & + & + & + \\
\hline Plumbaginaceae & & & + & + & + & + & + & + & + & + & + \\
\hline $\begin{array}{l}\text { Poaceae } \\
\text { Cerealia }\end{array}$ & & & + & + & + & + & + & + & + & + & $\begin{array}{l}+ \\
+\end{array}$ \\
\hline Polygalaceae & & & + & + & + & + & & + & & & \\
\hline \multirow[t]{2}{*}{ Polygonaceae } & Polygonum & & + & + & + & + & + & + & + & + & + \\
\hline & Rumex & & + & + & + & + & + & + & + & + & + \\
\hline Primulaceae & & & & & + & + & & & + & & + \\
\hline Ranunculaceae & Thalictrum & & + & + & + & + & & + & + & + & + \\
\hline Resedaceae & & & + & + & + & + & + & + & & + & + \\
\hline \multirow[t]{2}{*}{ Rosaceae } & Filipendula & & + & + & & + & + & & + & & + \\
\hline & Sanguisorba-type & & + & + & + & + & + & + & + & + & + \\
\hline Rubiaceae & Galium & & + & + & + & + & & + & + & + & + \\
\hline Saxifragaceae & & & + & + & + & + & + & + & + & + & + \\
\hline Scrophulariaceae & & & & & & + & + & + & + & + & + \\
\hline Solanaceae & & & + & + & + & + & & + & + & + & + \\
\hline Thymelaeaceae & & & + & + & + & + & + & + & + & + & + \\
\hline Urticaceae & & & + & + & + & + & + & + & + & + & + \\
\hline Valerianaceae & & & + & + & + & + & & + & & & \\
\hline Xanthorrhoeaceae & Asphodelus & & + & + & + & + & + & + & + & & + \\
\hline \multicolumn{12}{|l|}{ Steppe plants: } \\
\hline Arecaceae & Chamaerops & cf. humilis & & & + & + & 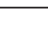 & & & & - \\
\hline Asteraceae & Artemisia & & + & + & + & + & + & + & + & + & + \\
\hline Elaeagnaceae & Hippophae & rhamnoides & & + & + & + & + & + & + & + & + \\
\hline Ephedraceae & Ephedra & & + & + & + & + & + & + & + & + & + \\
\hline Neuradaceae & Neurada & & & & + & & + & + & & & \\
\hline Nitrariaceae & Nitraria & & + & + & + & + & + & + & + & & \\
\hline Poaceae & Lygeum & cf. spartum & + & + & + & + & + & + & + & + & + \\
\hline Polygonaceae & Calligonum & & & + & + & + & + & + & & + & + \\
\hline Rhamnaceae & Ziziphus & & & & + & + & & & + & & \\
\hline \multicolumn{12}{|c|}{ Plants without signification: } \\
\hline \multirow[t]{3}{*}{ Pinaceae } & Pinus diplostellate-type & & + & + & + & + & + & + & + & + & + \\
\hline & $\begin{array}{l}\text { Pinus haplostellate- } \\
\text { type }\end{array}$ & & + & & + & + & + & + & + & + & \\
\hline & Pinus haploxylon-type & & + & + & + & + & + & + & + & & \\
\hline Ranunculaceae & & & + & + & + & + & + & + & + & + & + \\
\hline Rosaceae & & & + & + & + & + & + & + & + & + & + \\
\hline Rutaceae & & & + & + & + & & & & + & + & \\
\hline$?$ & $\begin{array}{l}\text { Gymnocardiidites: } \\
\text { fossil genus }\end{array}$ & $\begin{array}{l}\text { subrotunda: fossil } \\
\text { species }\end{array}$ & & & + & + & + & + & & & \\
\hline$?$ & $\begin{array}{l}\text { Tricolporopollenites: } \\
\text { fossil genus } \\
\text { also called: } \\
\text { Fupingopollenites }\end{array}$ & $\begin{array}{l}\text { sibiricum: fossil } \\
\text { species } \\
\text { wackersdorfensis: } \\
\text { fossil species }\end{array}$ & + & + & + & + & & + & + & & \\
\hline
\end{tabular}


- Cupressaceae: genera showing the Cupressus-Juniperus pollen-type cannot be identified, and cover a large temperature range;

-Aquatic plants living in freshwater environments;

- Mediterranean sclerophyllous plants, i.e. the trees, shrubs and herbs today characteristic of the thermo- and meso-Mediterranean ecosystems;

- Herbs that cannot be referred to the Mediterranean sclerophyllous plants with respect to the insufficient level of their pollen identification or by inhabiting different open environments;

- Steppe plants, i.e. Artemisia, Ephedra and Hippophae, characterizing the Mediterranean steppes and also including some subdesertic plants (Neurada, Nitraria, Calligonum, Lygeum, Ziziphus);

- Plants without significance because they live under various environmental conditions or by considering the low potential of their pollen identification.

Additional improvements also contribute to an optimal achievement of pollen analysis such as gentle techniques in processing sediments, mounting of the residue between cover-slip and microscope slide in glycerol (allowing examination of all the pollen faces by rotation and thus its reliable botanical identification), development of extensive photographic databases and modern pollen collections, use of modern pollen atlases, and when necessary examination of the pollen using scanning electron microscope (SEM).

Finally, counting of at least 100-150 pollen grains, excluding Pinus because it is often over-represented in marine or lacustrine sediments, makes our palynological approach fully comparable to that performed for late Quaternary studies. The results are shown in synthetic pollen diagrams (with the above mentioned groups), which suitably illustrate the vegetation changes (Suc, 1984).

Most of the studied localities correspond to coastal marine (often prodeltaic) sediments supplied by rivers, which, in addition to their independent dating by marine microplankton, are very appropriate to record the Mediterranean sclerophyllous plants as they inhabited the nearby hinterland.

The "Climatic Amplitude Method" was developed to specifically quantify climatic parameters of the Mediterranean lowlands during the Late Cenozoic (Fauquette et al., 1998a). The method which also takes into account the modern bioclimatic requirements of taxa (Fauquette et al., 1998b), is built on the statistical comparison between each past pollen assemblage and a database of more than 8,000 modern pollen records from various latitudes and longitudes in the Northern Hemisphere, thus allowing the transposition of the relative abundances of each taxon into climatic values. The most probable climate (mean annual temperature, mean annual precipitation, temperature of the coldest and warmest months, available moisture) for a set of taxa corresponds to the climatic range suitable for the maximum number of taxa. The climatic estimate is obtained as a climatic range and a "most likely value", which corresponds to a weighted mean. The "Climatic Amplitude Method" has been successfully tested several times on modern pollen records. Benefiting from high-quality pollen identifications (see above), the method is advantageous in comparison with another widely applied method, the "Coexistence Approach" (Mosbrugger \& Utescher, 1997; Utescher et al., 2014) because of its dual traits, qualitative-quantitative consideration for each taxon allowing delimitation of thresholds, and statistical treatment allowing processing of large numbers resulting from pollen counts. Inadequacies, inconsistencies and errors of the "Coexistence Approach" are stressed by Grimm \& Denk (2012) and Grimm et al. (2016) who notice the surprising uniformity of the climatic reconstructions for the Eurasian Cenozoic, continuously and everywhere qualified as "subtropical, perhumid or monsoonal conditions". Such a matter is explainable: (1) supremacy of good quality macrofloras used by this approach is obvious although they are restricted to almost similar humid palaeoenvironments; (2) pollen floras used by this approach that could really document the regional heterogeneity are of very poor taxonomic quality (see above) and very homogenous with only a small number of omnipresent taxa. Pollen analysis is thus unfortunately underused in the "Coexistence Approach" method. 


\section{Main flora and vegetation changes}

\section{Flora}

There has been a high diversity and heterogeneity of the Mediterranean flora since the beginning of Miocene, with a lot of megatherm and mega-mesotherm plants in addition to a large pool of taxa still present in the region today (table 2). Extinction of 108 thermophilous and hygrophilous taxa from the Mediterranean region is recorded, mostly during the Miocene and Pliocene, a few during the Quaternary. At the scale of a long-time range as the entire Late Cenozoic, successive extinctions can be regarded to have occurred according to latitude mainly and to longitude secondarily, while some refuge areas were established and persisted up to nowadays (Médail \& Diadema, 2009; Biltekin et al., 2015). Basically, extinctions were forced by repeated coolings in the mid-Miocene (13.6 Ma), just after the early-late Pliocene transition (3.6 Ma) and from the earliest Quaternary (onset of the Northern Hemisphere glaciations at 2.6 Ma) (e.g., Svenning, 2003; Suc et al., 2004). The Mediterranean physiography is characterized by West-East oriented barriers (mountains, the sea itself, and desert; figure 1). As a consequence, the thermophilous plants could not easily move southward during the climatic deteriorations and recolonize during the warmer phases the spaces previously abandoned. The Mediterranean floral history contrasts to that of North America where natural barriers are North-South oriented. Simultaneously, the East African monsoon exerted some influence that preserved some moisture in the Northeastern Mediterranean region (Popescu et al., 2006; Suc \& Popescu, 2005; Biltekin et al., 2015). The Mediterranean sclerophyllous plants (Olea, Ceratonia, Phillyrea, Pistacia, Nerium, Quercus ilex-type, etc.) were already present in the earliest Miocene. According to several syntheses (Kovar-Eder et al., 2006; Barrón et al., 2010; Velitzelos et al., 2014; Martinetto et al., 2015), macrofloras (leaves, fruits, seeds, cuticle, wood) appear richer than pollen floras from the viewpoint of thermophilous taxa which inhabited the Mediterranean region during the Miocene and Pliocene. The macrofloras have, however, a significance mainly restricted to moist places and a relatively limited representation for the herbs.

\section{Northwestern Mediterranean vegetation}

The Northwestern Mediterranean region is rich in pollen data that can be used successfully for reconstructing the vegetation during the last $23 \mathrm{Ma}$ (figure 1). Pollen counts provide reliable information for estimating palaeovegetation structures and the relative importance of ecological groups, supported by modern pollen records obtained from marine coastal deposits in the Gulf of Lions (Beaudouin et al., 2005b, 2007). Fifty-four localities were selected, distributed from the area between Barcelona and Nice (figure 2) and these are dated from the earliest Miocene to Holocene (figure 3). The following major vegetation changes can be addressed for this region (figure 3):

- The impoverished mangrove composed of Avicennia (megatherm element; Bessedik, 1981; Bessedik \& Cabrera, 1985) disappeared in the earliest Serravallian (at ca. 13 Ma; Bessedik, 1984; Jiménez-Moreno \& Suc, 2007);

- The swamps composed of Glyptostrobus ${ }^{1}$ (mega-mesotherm element), which probably replaced the Avicennia mangrove along the shoreline, strongly decreased at about 3.6 Ma and disappeared at about $3 \mathrm{Ma}$ from Southern France while they persisted up to at least $2 \mathrm{Ma}$ in Catalonia; a difference in moisture probably appeared at $3 \mathrm{Ma}$ between the northern and southern slopes of the Eastern Pyrenees as it exists today (appearance of the cold Tramontane and Mistral winds? Suc et al., 1999);

- Although they existed before, the Artemisia steppes began to spread at about $3 \mathrm{Ma}$ and significantly expanded at $2.6 \mathrm{Ma}$ (Vilobi del Penedès, Papiol) (Suc, 1984);

- During the early and middle Miocene, the Mediterranean sclerophyllous plants show relatively important percentages in some places close to low carbonate reliefs (e.g.: Portel - Sigean, Narbonne, Poussan - Issanka - Montbazin, Fabrègues); their development seems to have increased in the coastal areas during the early Pliocene (e.g.: Garraf 1, Papiol, Torrente del Terme, Ciurana, Vivès, Le Boulou, Cap d'Agde $1)$; they probably already constituted

1. Glyptostrobus was a member of the former Taxodiaceae family (as Taxodium, Sequoia, Metasequoia, Sequoiadendron, etc.) now included in the Cupressaceae family. Unidentified Taxodiaceae are listed as 'taxodioid' pollen. Sciadopitys, another genus previously incorporated into Taxodiaceae, now constitutes a new family, Sciadopityaceae. 
Figure 2 - Location map of selected significant pollen floras from the Northwestern Mediterranean region.

From Northeastern Spain to Southeastern France:

1, Vilobi del Penedès; 2, Sant Pau d'Ordal; 3, La

Rierussa; 4, Papiol; 5, Torrente del Terme; 6, Garraf 1;

7, Ciurana; 8, Can Cateura; 9, Banyoles; 10, Can Vilella;

11, Sampsor; 12, Sanavastre; 13, Vivès; 14, Le Boulou;

15, Leucate SC1; 16, Portel - Sigean; 17, Narbonne:

V. Hugo College; 18, Lespignan; 19, Montredon; 20,

Montady; 21, Cessenon; 22, Bernasso; 23, Cap d'Agde 1;

24, Issanka; 25, Poussan; 26, Montbazin; 27, Caunelle;

28, Montpellier; 29, Pichegu; 30, Pierrefeu 1; 31,

Fournès; 32, Vacquières; 33, Mirabel; 34, Autan 1; 35

Estagel - Bayanne; 36, Les Tamaris; 37, Carry-le-Rouet;

38, Aix-en-Provence - Venelles; 39, Vaugines; 40, La

Motte-d'Aigues; 41, Fabrègues; 42, Oraison (Flour); 43,

Villeneuve; 44, Les Mées (Périgoite); 45, Les Mées 1; 46,

Le Rochassas; 47, Châteauredon; 48, Escaravatier; 49,

Vence; 50, Le Gourg; 51, Carros; 52, Saint-Paul-de-Vence;

53, Saint-Isidore; 54, Saint-Martin-du-Var.
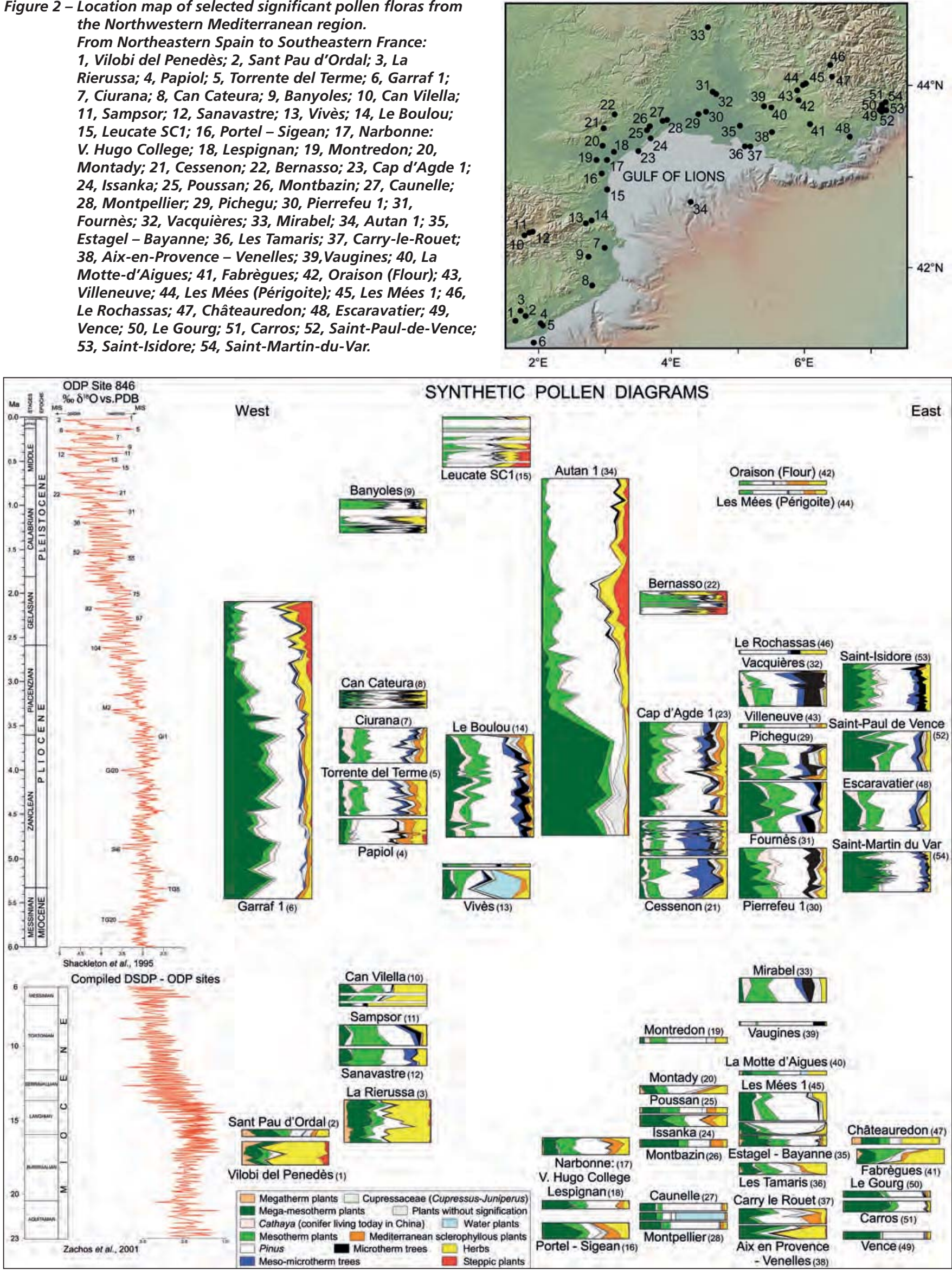

Figure 3 - Synthetic pollen diagrams distributed from West to East with respect to chronology and climatostratigraphy correlated with the reference oxygen isotope records.

MIS, Marine isotope stages.

Site numbers in brackets refer to Figure 2. 
sclerophyllous assemblages in some welldrained environments despite a climatic context that was, on the whole, humid (Suc et al., 1999).

\section{Vegetation of the entire Mediterranean region}

This regional process of major vegetation changes and its timing must be reconsidered at the entire Mediterranean scale (figure 4):

- The Avicennia mangrove disappeared earlier from the North Hungarian - Austrian (i.e. Pannonian) Basin and later from the South Mediterranean shorelines, ending with some residual locations in the southern Black Sea (Biltekin et al., 2015);

- Significantly younger, the disappearance of Glyptostrobus swamps followed in a similar way (Biltekin et al., 2015);

- More or less simultaneously depending of the region, the Artemisia steppe spread over the lands bordering the Mediterranean Basin (Suc et al., 1995; Popescu et al., 2010; Feddi et al., 2011).

Such a pattern of the main vegetation changes with a North-South succession implies a latitudinal organisation of the vegetation (i.e. zonation) since the earliest Miocene. The simultaneous presence of meso-microtherm (Cathaya, Cedrus, Tsuga) and microtherm (Abies, Picea) trees attests to an altitudinal belting of vegetation on higher ground (Suc, 1976a, 1989; Bessedik, 1984; Zheng, 1990; Jiménez-Moreno \& Suc, 2007). In addition, the high heterogeneity in the Mediterranean physiography (Meulenkamp \& Sissingh, 2003; Jolivet et al., 2006) with coastal reliefs, large islands and/or long peninsulas and episodic wide oceanic connections infers a high diversity of landscapes, supported by a large variety of soils, and therefore probably some mosaic distribution of plant communities. For a large part, the Miocene and Pliocene Northern Mediterranean forests evoke the modern evergreen broad-leaved and mixed mesophytic forests of Southern China (Wang, 1961; Hou, 1983), the pollen representation of which is well-known today (Huang et al., 2008; Zheng et al., 2008). The Late Cenozoic Southern Mediterranean open vegetation evokes the modern vegetation of the Middle East (Zohary, 1973; White, 1983).

All throughout the last $23 \mathrm{Ma}$, lands bordering the northern part of the Mediterranean Sea were inhabited by forests while the southern part was occupied by open vegetation, emphasizing the longterm persisting contrast between these realms which probably results from the onset of the Sahara Desert prior to the early Miocene (Lancelot et al., 1977; thesis ${ }^{\circ}$ 6, table 1; Suc et al., 1995; Fauquette et al., 2007; Jiménez-Moreno et al., 2007, 2010; Bachiri Taoufiq et al., 2008; Feddi et al., 2011). Such a contrasting context climatically predisposed the Mediterranean

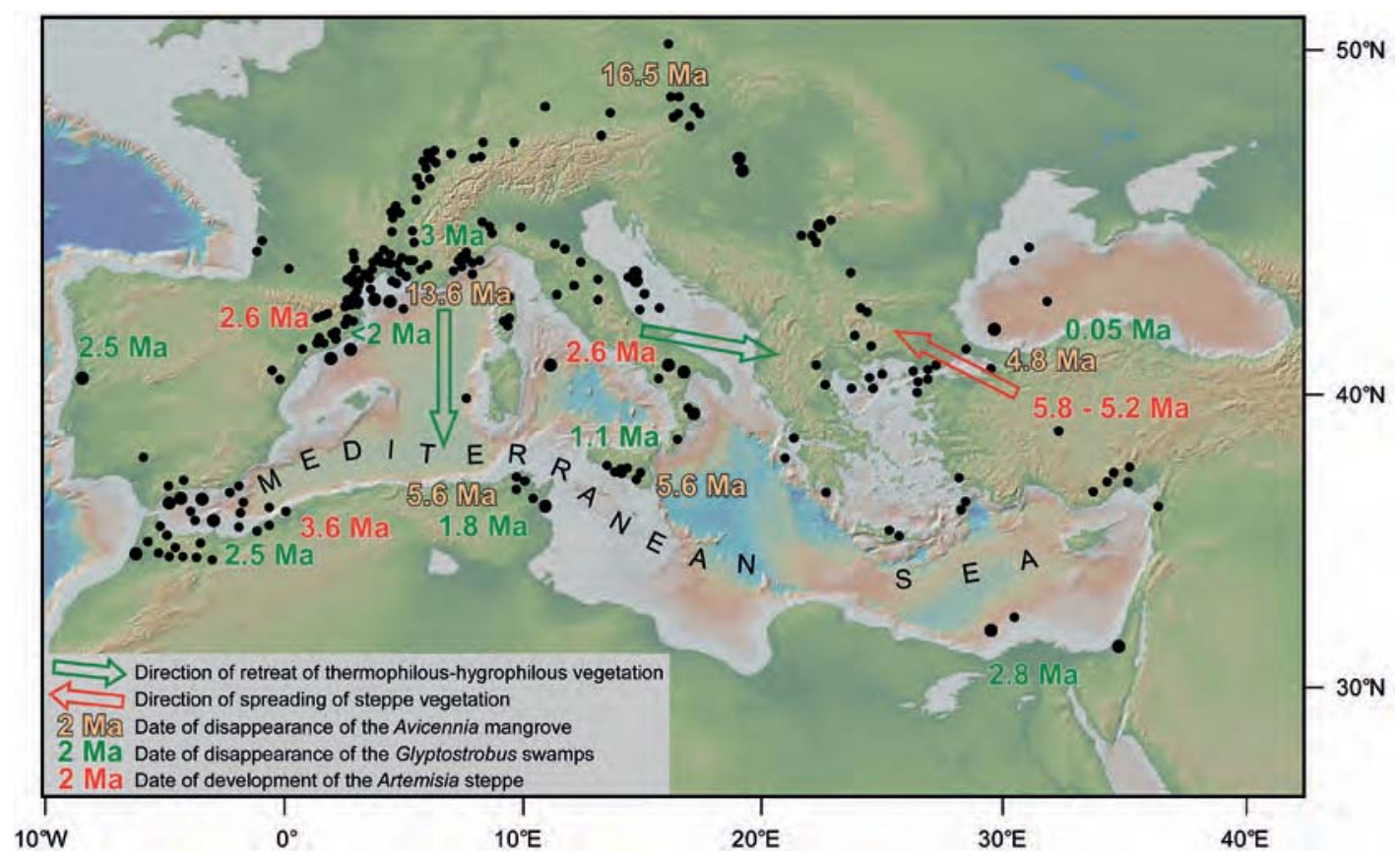

Figure 4 - Heterogeneity of the Mediterranean region with regard to the evolution of some plant ecosystems. 
Sea to be desiccated as soon as the last gateway connecting to the Atlantic Ocean closed (Fauquette et al., 2006) between 5.6 and 5.46 Ma due to tectonic activity (peak of the Messinian Salinity Crisis; Bache et al., 2015). Ecological consequences of the sealevel drop of the Mediterranean Sea at this time are still poorly known due to the lack of sedimentary records. However, a significant northward migration of the subdesertic plants is documented as a response to desiccation of the central basins (Fauquette et al., 2006; Popescu et al., 2007). Only one deep pollen record provides information on the vegetation of desiccated lands near Sardinia at the last evaporitic episode (5.47 Ma): open vegetation rich in halophytes and subdesertic plants with Mediterranean sclerophyllous plants probably inhabited the lowlands while a forest cover existed on the nearby massifs (Popescu et al., 2015).

\section{Mediterranean steppes}

Mediterranean steppes today constitute a crucial topic of discussion, probably because of their duality with respect to their xeric or thermic determinism (Quézel et al., 1980; Subally \& Quézel, 2002; Quézel \& Médail, 2003). Evidence of steppe assemblages, mainly composed of Ephedra, is rare in the early Miocene of the Northwestern Mediterranean region, as illustrated at Vilobi del Penedès and at La Rierussa (figure 3). Such ecosystems were controlled by a xeric determinism. Later, a first discrete development of the Anatolian steppes, composed of Artemisia mainly and Ephedra, occurred at about $6.2 \mathrm{Ma}$ and was followed by more pronounced expansion at 5.8-5.6 Ma, probably related to Antarctic glaciation and later with the desiccation phase of the Mediterranean Sea (Popescu, 2006; Popescu et al., 2010, 2016). At 5.2 Ma, Anatolian steppes crossed a critical threshold in their spreading that probably transformed them into a "regional pool" for their forthcoming wide expansion around the Mediterranean Sea (Popescu, 2006; Popescu et al., 2010, 2016). This affected the southern Mediterranean region at $3.34 \mathrm{Ma}$, related to cooling following the Zanclean - Piacenzian transition, then the northern Mediterranean region at $2.6 \mathrm{Ma}$ when the Northern Hemisphere glaciations commenced (figure 4). As shown by some plants associated with Artemisia - Ephedra steppes, the turnover from steppes with xeric determinism into those with thermic determinism occurred at around $1 \mathrm{Ma}$ (Suc et al., 1995). This is also the age considered for the onset of modern steppic environments in the Iberian Peninsula (Gonzalez-Sampériz et al., 2010). Improvements are being made in the distinction of Artemisia species or species groups using pollen grains, as initiated by Suc et al. (2004). During glacial-interglacial cycles, Artemisia steppes and mesophilous forests were in competition for occupation of the lowlands.

\section{Mediterranean sclerophyllous plants}

Early Pliocene pollen floras from the eastern part of the Iberian Peninsula require special attention: they show a latitudinal succession of prevalent taxa among the Mediterranean sclerophyllous plants which resembles the present-day zonation of Mediterranean vegetation. From the Roussillon area southwards to Barcelona, Quercus ilex-type and Phillyrea are indicated by frequent pollen grains with few Olea and Cistus and rare Pistacia (Suc, 1976a; Suc \& Cravatte, 1982). From Barcelona to south of the Ebre Delta, Olea is prevalent with Phillyrea and Cistus, Quercus ilex-type decreases and Pistacia is better represented in the pollen flora which also includes Nerium (Bessais \& Cravatte, 1988). Some subdesertic elements, such as Ziziphus, Calligonum, Lygeum and Nitraria are also present and Arecaceae (maybe corresponding to Chamaerops and/or Phoenix p.p.) increase (Bessais \& Cravatte, 1988). The pollen flora from Andalucia is similar and also includes Ceratonia (Feddi et al., 2011). Equally, herbs increase from North to South (Jiménez-Moreno et al., 2010). Such a latitudinal succession resembles the presentday replacement of meso-Mediterranean populations by thermo-Mediterranean populations, becoming progressively enriched in subdesertic plants (Quézel \& Médail, 2003). According to pollen records, Mediterranean sclerophyllous plants increased when megamesotherm plants became progressively rarer and then disappeared: it has been hypothesized that sclerophyllous Mediterranean ecosystems somewhat similar to the modern ones developed for the first time in a sustained way between 3.34 and $2.6 \mathrm{Ma}$ (Suc, 1984) but this time-interval is not yet well enough documented by pollen data to allow a detailed reconstruction of vegetation evolution at this time. However, according to Tzedakis 
(2007), several transient episodes with the Mediterranean seasonal pattern of rainfall may have occurred before the Pliocene that progressively led the sclerophyllous plants becoming more adapted to a dry season.

Conversely, data for analysing the development of the Mediterranean sclerophyllous ecosystems during glacial-interglacial cycles are abundant for the last $2.5 \mathrm{Ma}$. A lot of surface marine, lagoonal or lacustrine sediments from the Northwestern Mediterranean region illustrate that nowadays the Mediterranean sclerophyllous plants account for between 3 and $28 \%$ of the total pollen sum (Pinus excluded) (Cambon et al., 1997; Le Dantec et al., 1998; Suc et al., 1999; Beaudouin et al., 2007). A borehole covering the years 1950-1991, cored in the Rhône prodelta where sedimentation rate is fast (ca. $60 \mathrm{~cm} /$ year in the absence of disturbances as storms and/or floods), shows that the seasonal representation of Mediterranean sclerophyllous plants during their blooming period comprised between 3.79 and $8.52 \%$ of the total pollen sum, Pinus being excluded (Beaudouin et al., 2005b). Considering the large surface nowadays occupied by the meso-Mediterranean vegetation back of coastal ecosystems in Southern France, it is obvious that Mediterranean sclerophyllous plants are under-represented in coastal marine or lagoonal sediments. Therefore, we consider that a value higher than $3 \%$ in past pollen records is significant, outweighing potential biases due to pollen transport and/or preservation, and means an important development of Mediterranean sclerophyllous plants. In order to determine the relationship which may have existed since 3.6 Ma between climate evolution and development of the Mediterranean vegetation, we use the percentage curves in 13 accurately dated pollen localities (figure 5). These curves are plotted using the pollen ratio of "thermophilous/steppe elements" (figures 6-8), which is a reliable index of climatic changes in lowlands of the Mediterranean region as shown by long records, and correlated with reference to the oxygen isotope curve (Popescu et al., 2010; Joannin et al., 2008; Suc et al., 2010). Special attention is paid to significant peaks $(>3 \%)$ of the Mediterranean sclerophyllous plants in figures $6-8$, indicated by grey bands. In particular, the isolated peaks significantly greater than $3 \%$ and those grouped in clusters, even though of brief duration, are examined (indexed ' $\mathrm{a}-\mathrm{i}$ ' in figure 6; ' $\mathrm{j}-\mathrm{l}$ ' in figure 7; ' $\mathrm{m}-\mathrm{r}$ ' in figure 8):

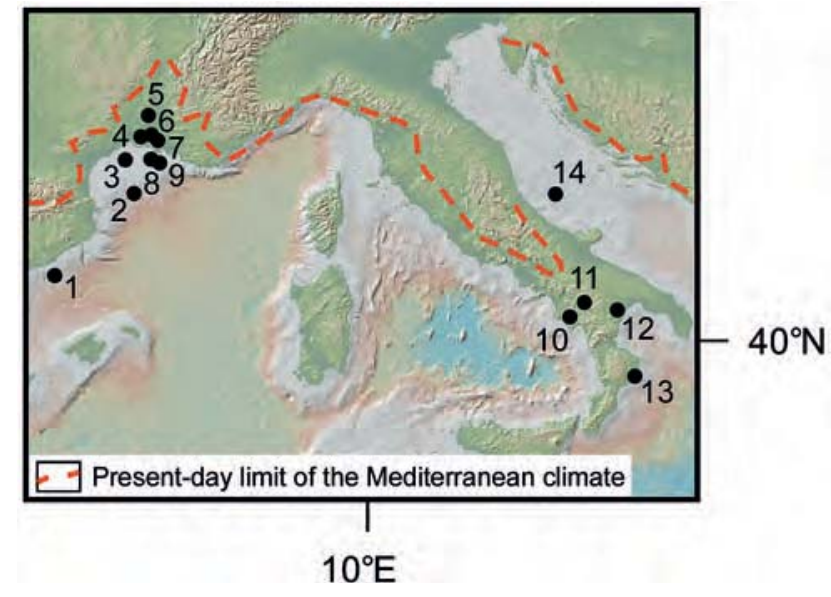

Figure 5 - Location map of pollen sites considered for reconstructing the history of the Mediterranean sclerophyllous plants since 3.6 Ma and the two sites showing last occurrences of Zelkova.

1, Garraf 1; 2, MD99-2348 and PRGL1-4;

3, 92K19; 4, Saint-Ferréol; 5, Piton; 6, Fangassier; 7, BF6; 8, 92K04; 9, 92K08; 10, Camerota; 11, Vallo di Diano; 12, Montalbano Jonico; 13, Crotone; 14, PRAD1-2.

Time-interval 3.6 - 0.9 Ma (figure 6):

- peaks 'a - c' coincide with relative minima of the ratio of "thermophilous/steppe elements" and are thus correlated with cooler phases corresponding to marine isotope stages (MIS) M2, KM2 and G10, respectively;

- location of peak ' $d$ ' is somewhat ambiguous as it coincides with a minor maximum of the ratio of "thermophilous/steppe elements" within a general lowering trend, and is correlated with the warmer MIS G3;

- the cluster of peaks ' $e$ ' corresponds for the most prominent peaks to a colder phase identified as MIS 98;

- the cluster ' $\mathrm{f}$ ' shows its most important maxima in its upper part, i.e. in correspondence with the minimum of the ratio of "thermophilous/steppe elements" correlated with MIS 86;

- the most important peaks of cluster ' $\mathrm{g}$ ' belong to a colder phase correlated with MIS 82;

- cluster ' $h$ ' is located within a minor cooling during a warm phase identified as MIS 45;

- cluster 'i' shows its major peaks located within a warmer phase correlated with MIS 39 while minor peaks correspond to a cooling correlated with MIS 38;

- at least two isolated peaks (between 'e' and ' $f$ ' and above ' $i$ ') correspond to coolings, MIS 90 and 36 respectively. 


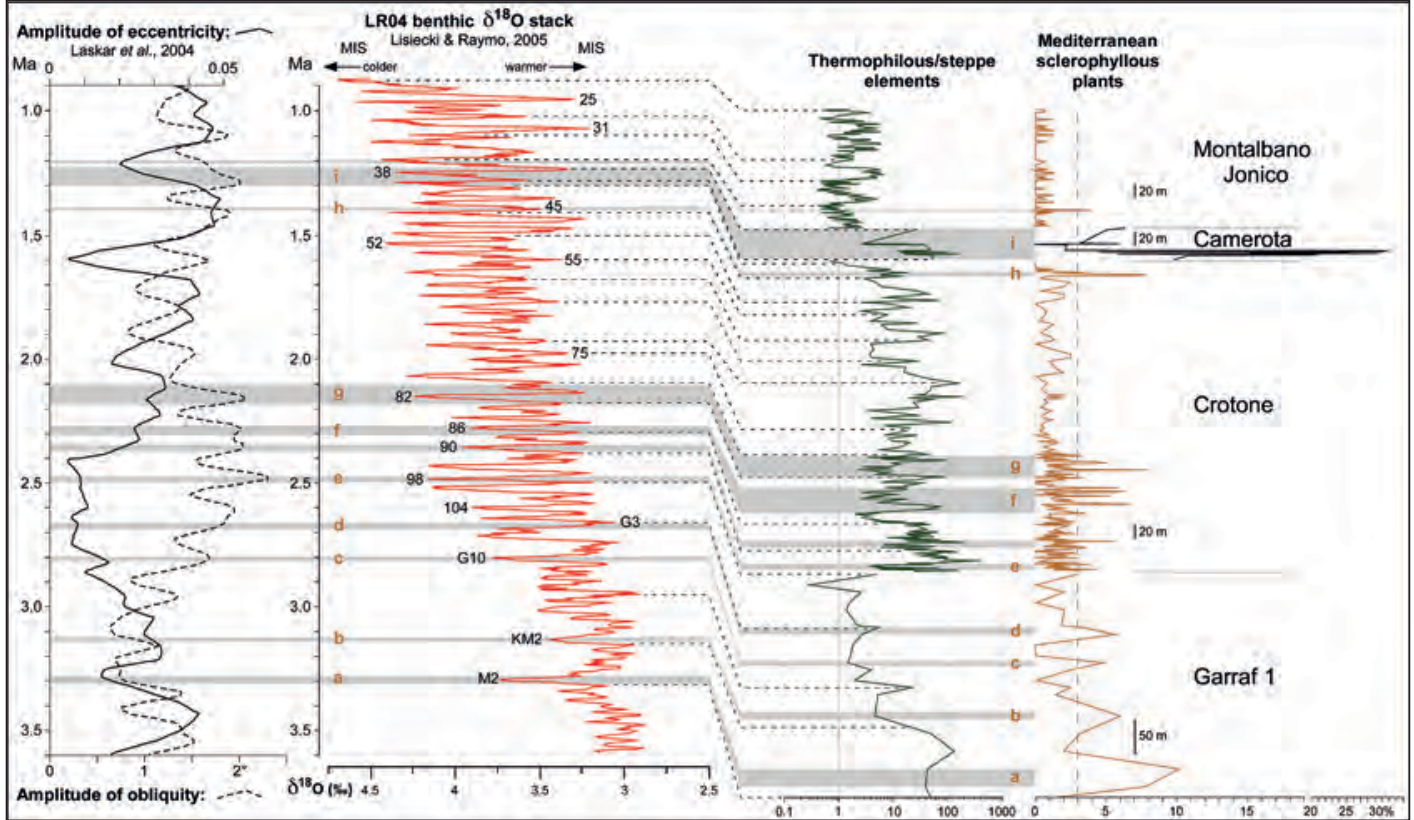

Figure 6 - History of the Mediterranean sclerophyllous plants between 3.6 and 0.9 Ma according to pollen records from four localities: Garraf 1 (Cravatte \& Suc, 1981), Crotone (Suc et al., 2010), Camerota (Brenac, 1984), Montalbano Jonico (Joannin et al., 2008).

The curve of percentages of Mediterranean sclerophyllous plants (Ceratonia, Nerium, Myrtaceae, Olea, Quercus ilex-type, Rhamnaceae, Pistacia, Phillyrea, Cistus, Phlomis cf. fruticosa, Rhus cf. cotinus), based on the total pollen sum (Pinus excluded), is plotted with the curve of the ratio "thermophilous/steppe elements", a reliable indicator of climatic changes.

Chronostratigraphic relationships with the reference oxygen isotope curve are indicated by dotted lines according to already established cyclostratigraphic correlations (Suc \& Popescu, 2005; Joannin et al., 2008; Suc et al., 2010).

Grey bands display isolated peaks or clusters of peaks of Mediterranean sclerophyllous plants exceeding $3 \%$ of the pollen sum and correlate them with the other proxies.

The amplitude curves of eccentricity and obliquity are constructed thanks to a mathematical calculation of their envelope, respectively.

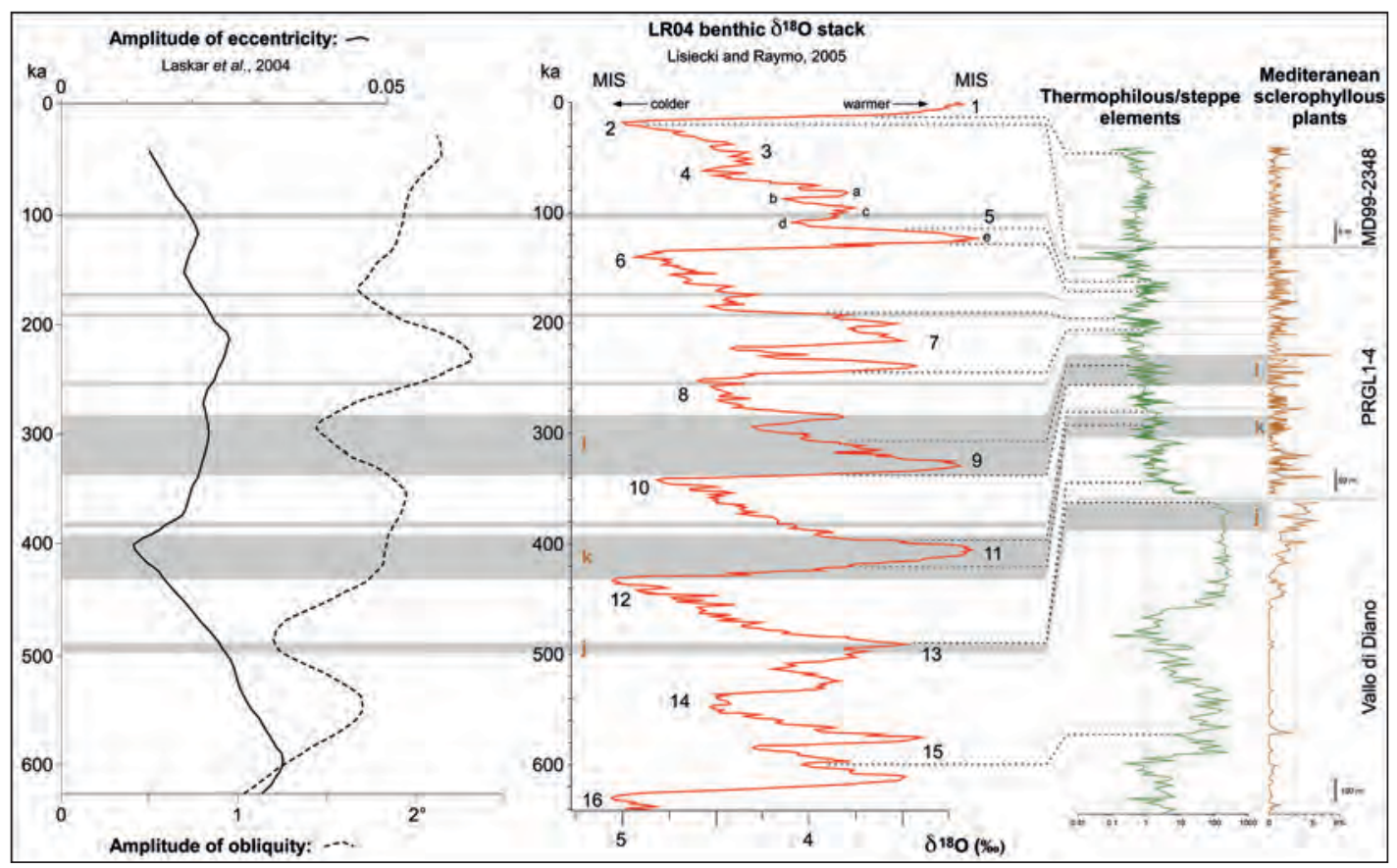

Figure 7 - History of the Mediterranean sclerophyllous plants between ca. 600 and 0.013 ka according to pollen records from three localities: Vallo di Diano (Russo Ermolli, 1994; Russo Ermolli \& Cheddadi, 1997), PRGL1-4 (Suc et al., in progress), MD99-2348 (Beaudouin et al., 2005a). Same explanations as for Figure 6. 
Time-interval 640 - 15 ka (figure 7):

- cluster ' $j$ ' coincides with a warm period correlated with MIS 13;

- cluster ' $k$ ' corresponds to a cold phase correlated with MIS 12;

- cluster ' 1 ' shows its minor peaks during a warm phase correlated with MIS 9 and its major peak during a warmer episode within MIS 8;

- an isolated peak between clusters ' $k$ ' and ' 1 ' belongs to a cold phase related to early MIS 10;

- the three isolated and minor peaks following cluster 'l' occurred during moderate warmings within cold MIS 8 (lower peak) and MIS 6 (two upper peaks);

- the last isolated minor peak is recorded in correspondence with a moderate warming correlated with MIS 5c (i.e. the SaintGermain 1 interstadial).

Time-interval 11,200 - 0 years for which climatic correlations are made with reference to the Greenland isotope curve GISP2 (figure 8):

- cluster ' $\mathrm{m}$ ' is located during a phase of weak decrease in temperature correlated with a transitional phase in the GISP2 curve characterized by low fluctuations around 4,500 yrs cal. BP;

- each of the three peaks of cluster 'n' match a cooler episode within a fluctuating period with prevalent cooler episodes in the GISP2 curve between 4,000 and 3,600 yrs cal. BP;

- the same observation is made for most of the peaks of cluster ' $\mathrm{o}$ ' in relation with a phase of greater amplitude fluctuations in the GISP2 curve between ca. 3,500 and 2,900 yrs cal. BP;

- a similar interpretation concerns peaks of cluster 'p' equating, on the whole, to a cooler period corresponding to prevalent coolings in the GISP2 curve $(2,300-1,700$ yrs cal. BP);

- the two peaks of cluster 'q' correspond to a cooling trend expressed by the ratio of "thermophilous/steppe elements" and to repeated decreases in temperature in the GISP2 record between 800 and 500 yrs cal. $\mathrm{BP}$;

- peaks of cluster ' $r$ ' resemble those of cluster 'p' and are correlated with a cooler phase in the GISP 2 curve between 400 and 200 yrs BP;

- the four isolated peaks before cluster ' $m$ ' match relative cooler phases according to the ratio of "thermophilous/steppe elements" and are related to decreases in the GISP2 record at ca. 10,200, 8,700, 7,200 and 5,200 yrs cal. BP, respectively.

For the interval $3.6-0.9 \mathrm{Ma}$, the peaks or clusters are irregularly paced, but most of them occurred during periods with decreases in temperature (figure 6). In the Garraf 1 record, the main pollen contributors to peaks 'a-d' are Olea, Phillyrea and evergreen Quercus (Suc \& Cravatte, 1982). In the lower part of the Crotone series (peaks 'e-g'), they are Pistacia, Olea and evergreen Quercus; in its upper part (peak 'h'), Olea and evergreen Quercus (Combourieu-Nebout, 1990). In the Camerota record (Brenac, 1984), the warm phase (lower part of cluster 'i') shows a predominance of Ceratonia and Olea replaced by that of Olea, Phillyrea and evergreen Quercus; the following cooler phase (middle part of cluster ' $i$ ') displays a minimum occurrence of Olea and evergreen Quercus; the uppermost warming phase (uppermost part of cluster ' $i$ '), shows a minor presence of evergreen Quercus. Olea is the main component of the minor peak of the lowermost part of the Montalbano Jonico series (Joannin et al., 2008).

Peaks or clusters from the interval $640-15$ ka are also irregularly paced; some of them can be referred to a cooling period, others to a warming phase (figure 7). The upper interglacial phase of Vallo di Diano (cluster ' $\mathrm{j}$ ') shows predominance of evergreen Quercus and, at a lesser level, of Pistacia and Olea (Russo Ermolli, 1994). In the PRGL1-4 record, clusters ' $k$ ' and 'l' and secondary peaks show predominantly Olea, Phillyrea and evergreen Quercus (Suc et al., in progress).

Most of the isolated peaks and clusters from the interval 11,200-0 years are correlated with cooler episodes (figure 8). Evergreen Quercus prevails in the isolated peaks and in clusters 'm - o'. Subsequently, Olea and sometimes evergreen Quercus or Phillyrea are the most important representatives of Mediterranean sclerophyllous plants in clusters ' $p-r$ '.

In a first approximation, it seems that the Mediterranean sclerophyllous plants were advantaged during cooling phases, maybe because of the opening of forested vegetation. However, these isolated peaks or clusters are not uniformly distributed through time (figures 6-8), indicating that temperature falls and correlative dryness increases are not the only forcings. Indeed, there is no direct relationship with the insolation curve at $60^{\circ} \mathrm{N}$ 


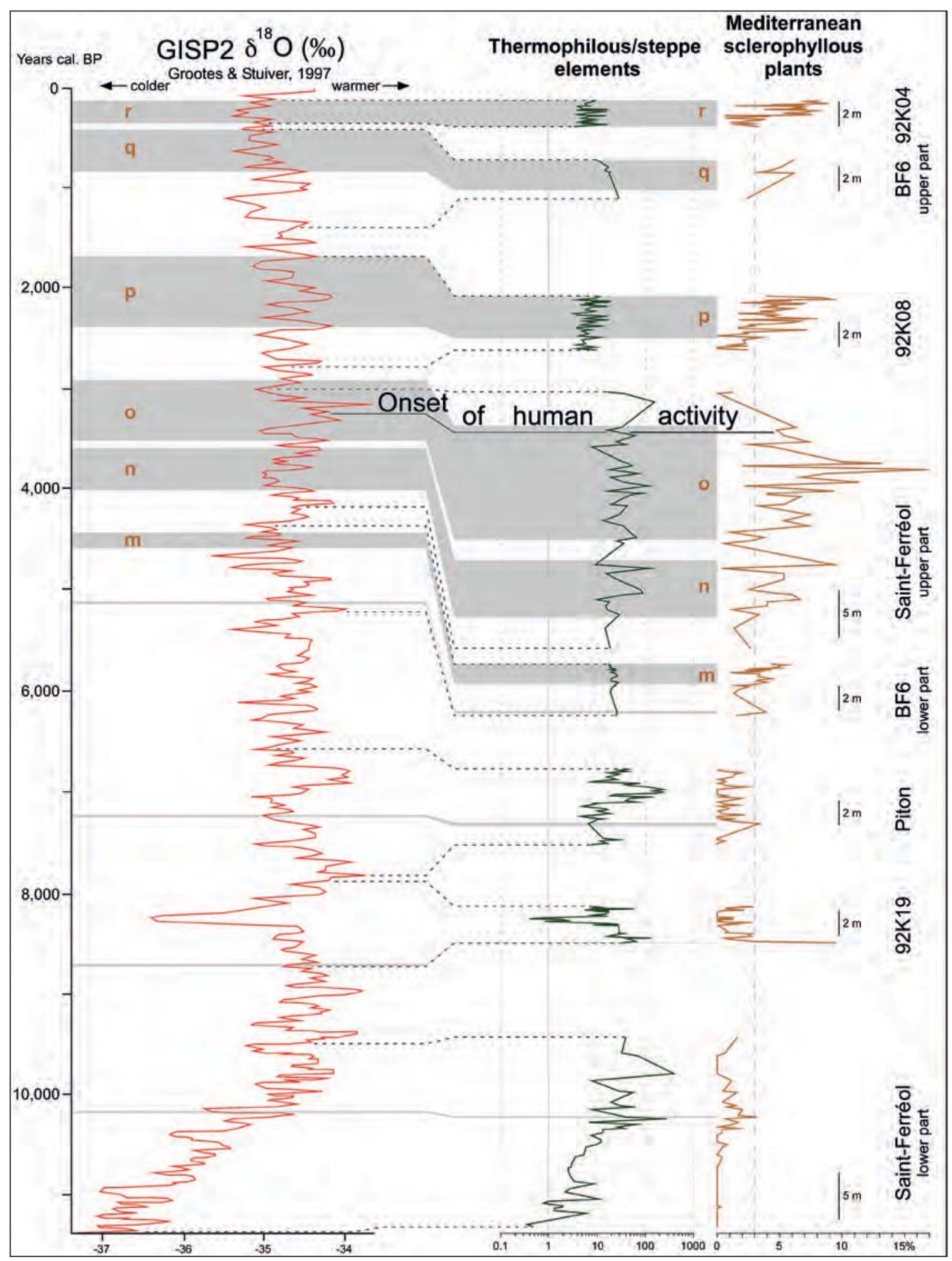

Figure 8 - History of the Mediterranean sclerophyllous plants since ca. 11,2000 years cal. BP according to pollen records from six localities: $92 K 19$ (Beaudouin et al., 2005a); $92 K 08$ and $92 K 04$ (thesis $n^{\circ} 1$ ), Piton (thesis $n^{\circ}$ 3); Saint-Ferréol (thesis $n^{\circ} 11$ ), BF6 (thesis $\left.n^{\circ} 27\right)$ - thesis references are in Table 1. Same explanations as for Figure 6 without the eccentricity and obliquity amplitudes not illustrated here.

but some correlations coincide with phases of relative higher amplitude of obliquity and simultaneously with phases of relative lower amplitude of eccentricity: e.g. peaks or clusters 'c-g', 'i' and 'k' (figures 6-7). Such phases of increased instability in seasonality (high amplitude of obliquity) and low variability in heat (low amplitude of eccentricity) (Berger, 1990) may have advantaged the Mediterranean sclerophyllous plants competing with other ecosystems within opening low altitude landscapes during colder periods. Mediteranean sclerophyllous ecosystems were widely developed in the Southen Italian Peninsula 
between 2.6 and 1.2 Ma as illustrated by the Crotone and Camerota successions (figure 6). Pollen records from Crotone and Montalbano Jonico document a similar palaeoclimatic evolution to those from Camerota and Vallo di Diano although their sedimentary context differs. The younger records, Montalbano Jonico and Vallo di Diano, exhibit a distinct retreat of the Mediterranean sclerophyllous plants (Combourieu-Nebout et al., 2015). This retreat may be considered as a consequence of the mid-Pleistocene revolution (at about $1 \mathrm{Ma}$ ) during which prevalent $41 \mathrm{kyr}$ glacial-interglacial cycles were replaced by $100 \mathrm{kyr}$ ones (Head \& Gibbard, 2005). As emphasized by Leroy (2007) and Tzedakis (2007), the relative shortness of glacials (although frequently repeated) compared to the length of interglacials before the midPleistocene revolution may have advantaged the Mediterranean sclerophyllous plants in their expansion. Subsequently, during the last $900 \mathrm{ka}$, this expansion may have been slowed down by the significantly increased length of glacials with respect to interglacials (Leroy, 2007; Tzedakis, 2007). The Rhône Delta (Camargue) is rich in pollen records showing close and almost continuous climatostratigraphic relationships with the oxygen isotope curve of the GISP2 ice-core (figure 8). Percentages of Mediterranean sclerophyllous plants show episodic maxima in the lower part of the series which are clustering after 5,000 years cal. BP, the highest ones of which (mostly composed of Quercus ilex-type) precede, by more than 2,000 years the onset of human activity dated at 3245 years cal. BP in the area (figure 8) (Arnaud-Fassetta et al., 2000). This is in agreement with the observations in the nearby Languedoc by Jalut et al. (2009) who propose some aridification process since 5,500 years cal. BP. The new Camargue data contribute to the debate on the climatic vs. anthropogenic forcing of the recent spreading of Mediterranean sclerophyllous plants (Beaulieu et al., 2005). A similar contrast in the representation of Mediterranean sclerophyllous plants is obvious in Southern Spain between the early mid-Pleistocene (Joannin et al., 2011) and the Holocene (CombourieuNebout et al., 2009). As in the case of steppes, the development of Mediterranean sclerophyllous plants is probably first due to climatic forcing and then accentuated by anthropogenic pressure. One must note that the last 50 kyrs correspond to high amplitude of obliquity and low amplitude of eccentricity (figure 7; Laskar et al., 2004). As an additional argument, we emphasize that Olea pollen is abundant in the youngest records from 92K08 and 92K04 cores (location in figure 5). These results highlight that pollen analyses at high time resolution are strongly needed.

The evolution of Mediterranean vegetation during the last 23 Ma can be summarized as follows: surface reduction of some plant ecosystems was counterbalanced by the spread of other ones: Avicennia mangrove vs. Glyptostrobus swamps, evergreen subtropical forests vs. Mediterranean sclerophyllous ecosystems, herb ecosystems vs. Artemisia steppes, and lastly mesophilous forests vs. Artemisia steppes during climatic cycles.

\section{Climatic evolution}

The climatic evolution of the Mediterranean region can be synthetically subdivided into three major phases:

- During the entire Miocene, the early Pliocene and the beginning of late Pliocene (i.e., from 23 to $3.37 \mathrm{Ma}$ ), a climatic rhythm existed with some seasonal dryness that could vary according to age and geography; low amplitude in seasonal temperature variation is also assumed in a subtropical context (Bessedik, 1984; Jiménez-Moreno \& Suc, 2007; Jiménez-Moreno et al., 2007); - The time interval 3.37 - 2.6 Ma can be regarded as a transitional period characterized by the emergence of a Mediterranean seasonal rhythm with summer drought and cooler winters (Suc, 1984; Popescu et al., 2010);

- From 2.6 Ma, the earliest glaciations in the Northern Hemisphere caused generalized dryness and colder conditions during glacials with highly contrasting seasons. On the contrary, moister and warmer conditions developed during interglacials. Such climatic trends were repeated during secondary fluctuations (Suc, 1978; CombourieuNebout et al., 2000).

A strong North-South gradient was continuously superimposed on this general context, characterized by a southward dryness and temperature increase during warmer periods, and a decreasing climatic contrast during colder periods (Suc et al., 1995; JiménezMoreno \& Suc, 2007). Palaeoclimatic quantifications allow an estimation of this dual 


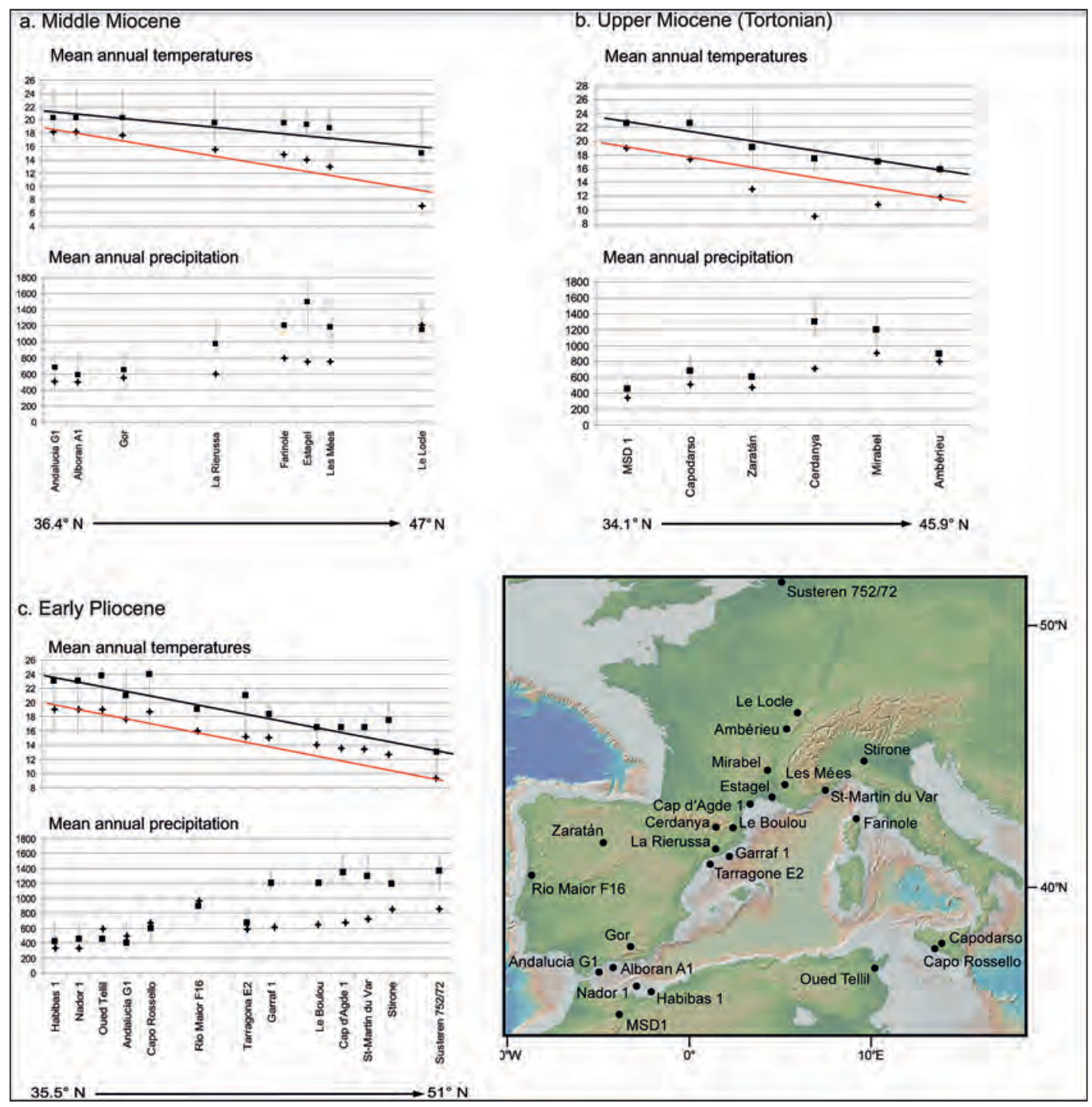

Figure 9 - Climatic reconstructions from pollen data (climatic interval and most likely value) in Western Europe and Mediterranean region showing the gradients of temperature (mean annual temperature in ${ }^{\circ} \mathrm{C}$ ) and precipitation (mean annual precipitation in $\mathrm{mm}$ ) for (a) the middle Miocene (Langhian/Serravallian, 14 - 15 Ma), (b) the late Miocene (Tortonian, 10 Ma), (c) the early Pliocene (Zanclean, 5.3 - 5 Ma). Modern values are indicated by a cross to show the differences between modern and past latitudinal gradients (modified from Fauquette et al., 2007).

gradient, in humidity and temperature, over time (Fauquette et al., 2007). However, the precipitation seasonality is not quantified through this method.

The results of the climatic quantification based on pollen samples covering the middle Miocene period (15.97 - 11.63 Ma) show that mean annual temperatures (MAT) were higher than today at all sites ( 2 to $8^{\circ} \mathrm{C}$ higher) and that mean annual precipitation (MAP) was higher than today in Southern France, Corsica and North Eastern Spain (between $400 \mathrm{~mm}$ and $700 \mathrm{~mm}$ higher) and almost equivalent to modern values (maximum $200 \mathrm{~mm}$ higher) in Southwestern Europe (figure 9a; Fauquette et $a l .$, 2007). From North to South, annual temperatures increased but annual precipitation decreased. The thermic gradient was clearly weaker than the modern one. On the basis of the reconstructed values from pollen data, the thermic gradient in Western Europe is estimated to have been around $0.48^{\circ} \mathrm{C}$ per degree in latitude during the middle Miocene (Fauquette et al., 2007).

During the Tortonian (11.63 - 7.24 Ma), the climate was warm and humid in Northwestern Europe (MAT 4 to $9^{\circ} \mathrm{C}$ and MAP 100 to 600 $\mathrm{mm}$ higher than today) and warm and dry in the South Mediterranean region (MAT 3 to $4^{\circ} \mathrm{C}$ higher and MAP less than $200 \mathrm{~mm}$ higher than today) (figure $9 b$ ). The climatic estimates show that the North-South climatic gradient that existed during the Tortonian was similar to that of the present-day, with increasing 
temperature and decreasing precipitation, but with higher temperatures. On the basis of the reconstructed MAT, Fauquette et al. (2007) showed that the thermic gradient was around $0.6^{\circ} \mathrm{C}$ per degree in latitude.

During the earliest Pliocene (5.3 - 5 Ma), the climatic reconstructions show that the average climate was warm and humid in Europe and the North Mediterranean region (MAT 1 to $4^{\circ} \mathrm{C}$ and MAP 400 to $700 \mathrm{~mm}$ higher than today), and warm and dry in the South Mediterranean region ( 1 to $5^{\circ} \mathrm{C}$ warmer and at least as dry as today) (figure 9c; Fauquette et al., 1998a, 1999, 2007; Fauquette \& Bertini, 2003). A North-South climatic gradient existed at the beginning of the Pliocene with, as today, increasing temperatures and decreasing precipitation. The thermic gradient is estimated to have been around $0.6^{\circ} \mathrm{C}$ per degree in latitude (Fauquette et al., 1999, 2007).

Our results thus confirm the existence of a North to South temperature gradient and a South to North precipitation gradient during the Neogene, but it appears that clearly the thermic gradient changed through time. Our results place the transition from the weak thermic gradient of the middle Miocene to the modern-like gradient of the Pliocene during the late Miocene, just before or during the Tortonian. The precipitation gradient was more pronounced during the Neogene than it is today. The transition to the modern gradient seems to have occurred during the lower Pleistocene, at the time of the earliest Northern Hemisphere glacial-interglacial cycles.

The climate of these first cycles has been reconstructed based on the Semaforo pollen sequence (lower part of the Crotone series: figures 5-6; Combourieu-Nebout, 1993) which covers the period between 2.46 and 2.11 Ma, i.e. nine glacial/interglacial cycles (Klotz et al., 2006). Our estimates indicate higher temperatures and precipitation than today during interglacials (MAT $\sim 3^{\circ} \mathrm{C}$ higher, MAP 500 mm higher), but temperatures were equivalent to or lower than today and precipitation equivalent to modern levels during glacials. Moreover, throughout consecutive interglacials, a trend toward a reduction in annual and winter temperatures and toward higher seasonality is observed. During consecutive glacials, a trend toward a reduction in all temperature parameters is evident. Finally, the climatic amplitudes of the interglacial-glacial transitions progressively increased through time (Klotz et al., 2006). In the Rhône Delta, the last spreading of Mediterranean sclerophyllous plants due to climate significantly preceded the onset of human activity.

\section{History of some emblematic plant taxa}

This synthesis would not be complete without considering the biogeographical history of some woody taxa. As a complement to the reviews published by Biltekin et al. (2015) and Magri et al. (2017), we pay attention to three taxa, the behaviour of which over time may significantly complete our understanding of the history of peri-Mediterranean vegetation and the onset of the modern ecosystems.

\section{Microtropis fallax Pitard (Celastraceae)}

This pollen grain is one of the few to benefit from identification at the species level because its morphology is very specific within the genus Microtropis and itself within the Celastraceae family, as argued by LobreauCallen \& Suc (1972). That fact should not be lost by Bertini \& Martinetto (2011: p. 240) in their claim that the correct identification of this taxon may require observation by SEM. Although we have SEM photographs, their publication is of little value in the identification of pollen of Microtropis fallax because the decisive characters concern the inner structure of the pollen membrane and not its surface ornamentation. The species is rarely but continuously recorded around the entire Mediterranean Sea s.l. (figure 1) from the early Miocene to early Pleistocene inclusive (table 2) (detailed distribution in theses $n^{\circ} 2-4$ 5-6-7-9-10-13-14-16-17-21-23-25-26-29: table 1). Today, Microtropis fallax is confined to two localities from Vietnam (Merrill \& Freeman, 1940) where it is a constituent of the evergreen broad-leaved forest living under warm climate with dry summer (3 months) and very moist autumn, strongly influenced by the nearby sea (Vidal, 1960). It can be hypothesized that M. fallax participated with Mediterranean sclerophyllous plants within ecosystems adapted to dry soils during the Miocene and early Pliocene, then disappeared when the temperature fall became too intense. M. fallax is not reported in the European macrofloras that are mainly documenting the 
moister forest ecosystems. Its absence may be explained by its ecological requirements for seasonally dry environments.

\section{Zelkova (Ulmaceae)}

The history of Zelkova was reported at the Northeastern Mediterranean scale by Biltekin et al. (2015). The recent discovery of the living plant in Sicily (Z. sicula di Pasquale, Garfi \& Quézel: di Pasquale et al., 1992; Quézel et al., 1993) requires us revisit its pollen records in the Northwestern Mediterranean region. Follieri et al. (1986) provided evidence of its last record in pollen successions from the Rome area at about 31,000 years BP. Recently, two offshore cores provided long pollen records, PRGL1-4 in the Gulf of Lions (Suc et al., in progress) and PRAD1-2 near the Gargano Peninsula (thesis ${ }^{\circ} 12$ : table 1 ) (figure 5). In the PRGL1-4 core, Zelkova occurs during each warm phase whatever its intensity, accompanied by Pterocarya, up to the end of the Last Interglacial (ca. $70 \mathrm{ka}$ ). They are both absent from all the colder phases since $500 \mathrm{ka}$, and that shows their extreme frailty during the recent glacial-interglacial cycles. In the PRAD1-2 core, at a latitude closer to Sicily, they are both present during the Last Interglacial and recorded episodically during the Last Glacial and the Holocene up to 6,000 years cal. BP., a little younger age than considered by Magri et al. (2017), suggesting its elimination in the Gargano Peninsula was caused by Man. Such recent evidence supports the continued survival of Zelkova up until today in Sicily. Quézel et al. (1993) were surprised by the modern occurrence of Zelkova in Sicily. Surprising too is the present-day absence of living remnants of Pterocarya in the Central Mediterranean region.

\section{Cedrus (Pinaceae)}

Three species are now accepted within the Cedrus genus: C. deodara (Roxb. Ex D. Don) G. Don, C. atlantica (Endl.) Manetti ex Carrière, and C. libani A. Rih. (The Plant List, 2013). These species live today in disjunct distribution areas (Quézel, 1998): C. deodara in the Himalayas realm, from Afghanistan to Nepal; C. atlantica in Northern Africa (Morocco and Algeria); C. libani in the Eastern Mediterranean region (Turkey to Lebanon) including $C$. brevifolia (Hook. f.) Henry, a taxon restricted to Cyprus (figure 10). Such a distribution has never been successfully explained. According to molecular clock estimates, C. deodara diverged at about $55 \mathrm{Ma}$, C. atlantica between 20 and $17 \mathrm{Ma}$ while C. libani and C. brevifolia separated between 8 and $5 \mathrm{Ma}$ (Qiao et al., 2007).

A first synthesis of the history of Cedrus was attempted by Pons (1998) despite only a limited documentation of macroremains and insufficient information from pollen records. However, the ancient origin (Lower Cretaceous?) of the genus seems to be established as attested by the occurrence of some Cedrus-like pollen grains in Upper Cretaceous deposits from central France (Bassil et al., 2016). The Cedrus bisaccate pollen is easily identifiable thanks to the jointed shape of its air-sacs and thickness of its cappa (Van Campo-Duplan, 1950) and the long walls of the large alveoli of the air-sacs (Sivak, 1975). Such an homogenous pollen morphology makes it difficult to identify isolated pollen grains at the species level for which Aytug (1961), however, indicated some distinctive characters: slightly thicker cappa in $C$. deodara, thinner cappa in $C$. atlantica, and with lateral crests in $C$. libani. In addition, the longest walls of the large alveoli of the airsacs can be observed in C. deodara.

Now we have at disposal enough high-quality pollen data to reconstruct a reliable history of Cedrus for the Late Cenozoic, particularly for the Mediterranean region s.l. A thorough review of Quaternary Cedrus records (pollen grains and macroremains) in Southern Europe was provided by Magri (2012) and completed by Magri et al. (2017), leading to a reconstruction of its history around the Mediterranean Basin. A few Cedrus pollen grains have been recorded on both sides of the Arctic Ocean, in the New Siberian Islands (Suan et al., 2017) and the Mackenzie Delta (Salpin et al., accepted) where it confirms a first presence, observed by Rouse \& Srivastava (1972), during cooler phases surrounding the early Eocene Climatic Optimum, i.e. at 58 $54 \mathrm{Ma}$ and 50 - $38 \mathrm{Ma}$ (Suc, unpublished). These findings reveal a high potential on the American and Eurasian continents for unravelling the history of Cedrus (figure 10).

\section{North America}

The Cenozoic history of Cedrus in North America is poorly documented: about ten localities are reported by Thompson (1991) and Graham (1999), mostly in the Western 

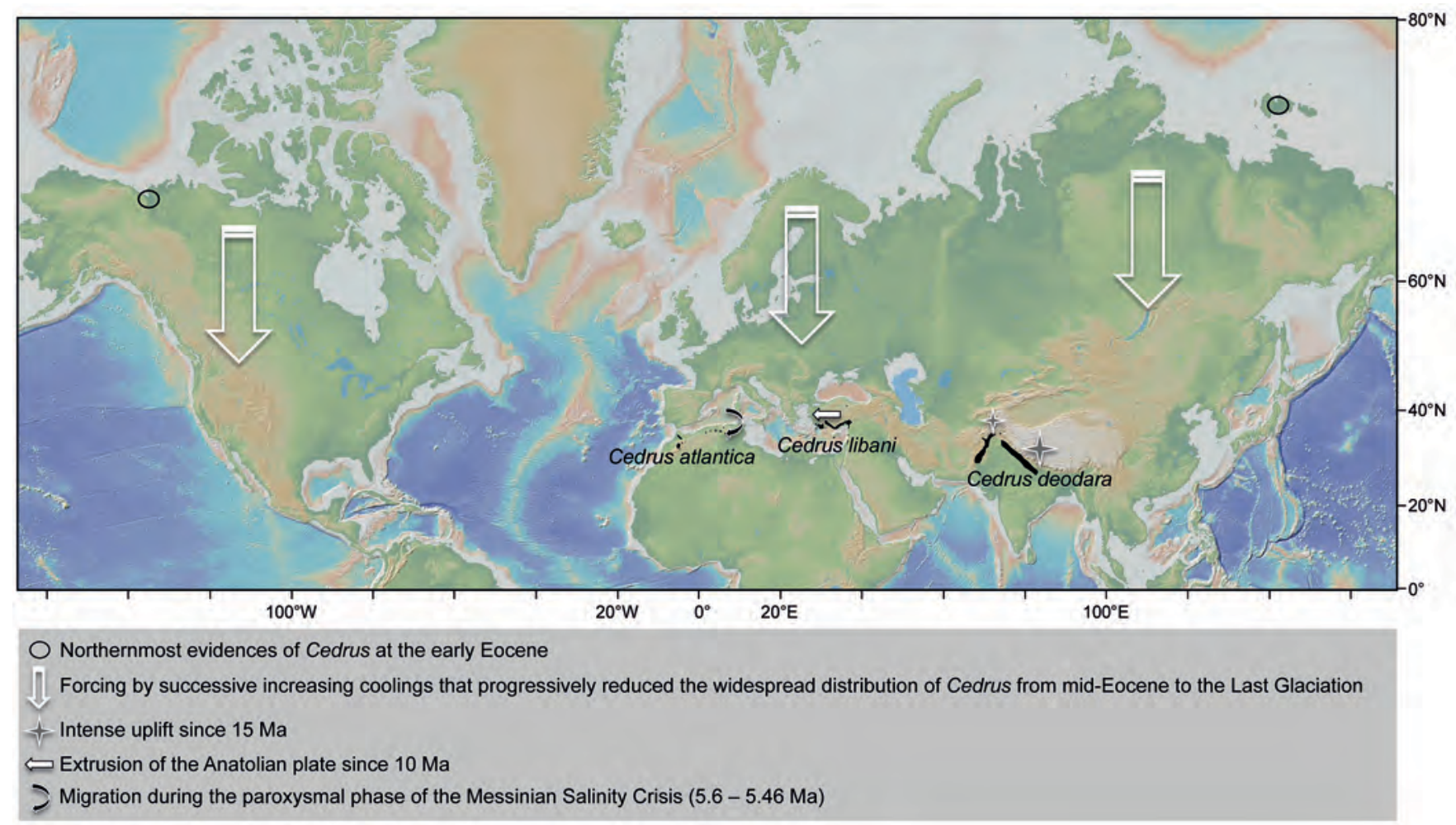

Figure 10 - North planisphere showing (1) the present-day distribution (in black) of the three living species of Cedrus, (2) the highest latitudinal places where the genus is recorded from early Eocene deposits, (3) the climatic forcing causing its weakening and surface regression, and (4) the intense geodynamic events which could be at the origin of the present refuges.

USA along the Rocky Mountains, the most important of them concerings the late Miocene (Leopold \& Denton, 1987) and the youngest the mid-Pliocene (Graham, 1999). The conditions and timing of the extinction of Cedrus from North America are enigmatic. Is there some relationship with the North-South alignment of the Rocky Mountains? Was the competition too hard with Tsuga still alive on the two sides of the continent?

\section{Eastern Asia}

The history of Cedrus deodara, today restricted to the southern slope of the Himalayas, is better constrained (figure 10). According to Hsü (1983), Cedrus seems to have been widespread during the Paleogene (from the Sakhalin Island to Inner Mongolia and Eastern China) and Miocene (from the Tibet Plateau to Eastern China). It has also been recorded from the early Miocene of Southern Myanmar (Popescu, unpublished). Hsü (1983) showed the restriction of Cedrus to the Tibet Plateau during the Pliocene and early Pleistocene and discussed its migration to the southern slopes of the Himalayas during the Pliocene. However, Cedrus could have occupied a larger area on both sides of the Himalayas before the uplift of the Tibet Plateau. Uplift started in the mid-Eocene, with repeated strong phases, mainly in the early Oligocene and since the mid-Miocene (15 Ma; Wang et al., 2012), during which time Cedrus was eliminated from the northern part of the mountain chain. Cedrus persisted in Southwestern China up until the late Pliocene from where it was probably eliminated by the onset of dry winters and early springs (Zhou et al., 2018). In addition, it cannot be excluded that this cedar may have had a larger extent to the West according to the occurrence of some pollen grains close to those of $C$. deodara up to the early Pliocene in the Northwestern Mediterranean region. Accordingly, a reduction of area similar to that of Cathaya and Tsuga may have affected this species.

\section{Western Asia}

Biltekin et al. (2015) assume that the early to mid-Miocene cedar from Anatolia refers to the $C$. libani $-C$. brevifolia lineage while the late Miocene - early Pliocene cedar is referable to C. libani. They show that Cedrus continuously inhabited the Anatolian reliefs up until the development of Artemisia steppes 
that probably fragmented the tree populations. Maybe the Middle East cedar resulted from an isolation process of the Anatolian Peninsula forced by intense tectonic extrusion since ca. $10 \mathrm{Ma}$ (figure 10; Barka, 1992; Meulenkamp \& Sissingh, 2003; Jolivet et al., 2006). During the late Miocene, propagation of the North Anatolian fault halted, that resulted in relief uplift (Armijo et al., 1999; Karacaş et $a l ., 2018)$. This hypothesis is supported by spreading of Cedrus pollen in late Messinian sediments from the Dardanelles Strait (Melinte-Dobrinescu et al., 2009). It is also consistent with the proposed age of genetic divergence of $C$. libani between 8 and $5 \mathrm{Ma}$ (Qiao et al., 2007).

Located at the junction between the Middle East and Asian realms, the South Caucasus area (Georgia) displays a dual history of Cedrus, mainly based on pollen grains, since the mid-Eocene. A fossil species and probably C. deodara and C. libani co-existed from the latest Miocene to mid-Pleistocene (Shatilova et al., 2011). C. atlantica is also indicated by the same authors as present during the late Miocene and early Pliocene. C. deodara would have persisted in the South Caucasus area up to the Last Glaciation (Shatilova $e t$ $a l ., 2011)$ and is replaced today by re-introduced C. libani (Denk et al., 2001). This illustrates how complex the history of Cedrus is in Eurasia due to the co-existence of fossil species and the emergence of the modern ones; the history is arduous to decipher because of the lack of fossil macroremains and difficulty in distinguishing the species using pollen morphology alone.

\section{Europe and North Africa}

The history of cedar in Europe is also complex. Cedrus was pointed out in relation to the occurrence of Mediterranean massifs since the Oligocene (Fauquette et al., 2015), that confirms its ancient presence on the continent (Ferguson, 1967). In Southern France (Languedoc), a rich early Pliocene assemblage suggests the existence of a dominant fossil Cedrus species, indicated by a coarser pollen grain (with thick cappa and dense alveolate network in the air-sacs) (Suc, 1981), consistent with the assumption of Pons (1964). In addition, several other pollen grains show a morphology close to that of $C$. atlantica and rare specimens are similar to $C$. deodara. Progressively, Cedrus disappeared during the Neogene from the higher latitudes to survive at lower latitudes, especially in some islands (Corsica, Sardinia) and the Hellenic, Italian and Iberian peninsulas where the species C. atlantica prevailed and persisted in this area up to the mid-Pleistocene (figure 10). Abundant pollen data from the Moroccan depression between the Rif and Atlas mountains and from the Chelif Basin in Algeria, do not show the occurrence of Cedrus during the Tortonian and early Messinian (thesis $\mathrm{n}^{\circ}$ 2, table 1; Chikhi, 1992). First occurrences of cedar in North Africa are indicated in the latest Messinian (i.e. during the desiccation phase of the Mediterranean) and earliest Zanclean in West Morocco (thesis $n^{\circ} 28$, table 1; Warny et al., 2003) and the early Pliocene of Northern Tunisia (thesis $n^{\circ} 24$, table 1) and Northern Morocco (JiménezMoreno \& Fauquette, unpublished). We can hypothesize that the paroxysmal desiccation phase of the Messinian Salinity Crisis (5.6 - 5.46 Ma; Bache et al., 2015) offered Cedrus the opportunity to migrate to North Africa, maybe from the Sardinian highlands considering the large amount of cedar pollen (including C. atlantica) in latest Messinian - earliest Zanclean deposits offshore of this island (Popescu et al., 2015). A second possibility is migration from the Calabrian and/ or Sicilian mountains (Suc and Bessais, 1990; Fauquette et al., 2006), despite the substantial distance to cross (figure 10). Contrasting with the hypothesis of Qiao et al. (2007) and AlbaSánchez et al. (2018), migration of Cedrus to North Africa was probably impossible via the Alboran domain because it was partly covered by oceanic waters during the paroxysm of the Messinian Salinity Crisis (Bache et al., 2012,2015 ) probably because of the preexistence of the Gibraltar Strait (Capella et al., 2018). As a last hypothesis, Cedrus could have already existed, albeit not significantly, in the Rif Mountains (a pollen grain was recorded in the Tortonian sediments of the Irhachâmene section, in Northern Morocco; Achalhi et al., 2016) and would have benefited from the closure of the Rifian corridor at about $7 \mathrm{Ma}$ (Capella et al., 2018) for colonizing the Middle and Tell Atlas mountains (figure 10). In this particular case, movement of Cedrus into North Africa could have occurred prior to the Messinian Salinity Crisis, and would have been assisted by the Rif orogen (Capella et al., 2017). In the Alboran Sea, there is weak evidence of Cedrus pollen offshore Algeria and Morocco in the latest Pliocene (Suc, 1989; Feddi et al., 2011) while it is rarely recorded 
in Southern Spain since the mid-Miocene (thesis $\mathrm{n}^{\circ} 17$, table 1; Jiménez-Moreno et al., 2010; Suc, unpublished). This hypothesis, supported by new data, offers reliable solutions to the questions asked by Magri (2012) and Magri et al. (2017). Especially, it provides robust information because most of the pollen data come from prodeltaic sediments forced by river supply and undisturbed by long-distance wind transport, suspected to have biased some late Quaternary European lacustrine records (Magri \& Parra, 2002; Magri, 2012; Magri et al., 2017). Otherwise, the persistence of Cedrus in Southern Spain during the late Pleistocene is still debated (Postigo-Mijarra et al., 2010; Joannin et al., 2011; Alba-Sánchez et al., 2018).

Once established in Morocco, Cedrus was helped by the uplifting Rif Mountains that peaked during the Pliocene (Romagny et al., 2014) and led, at mid to high altitude, to wetter and cooler climatic conditions more suitable for this conifer. Cedrus atlantica was probably saved from extinction by its migration from Europe to North Africa which offered new habitats protecting it from the forthcoming glacials (figure 10), especially from those of the late Pleistocene which decimated the European cedar populations and made the North African ones highly unstable (Cheddadi et al., 2009). Cedrus almost disappeared during medieval times from most of the pollen records, indicating its regression to its present-day stands on mountain crests in the Rif and Atlas (Muller et al., 2015).

To summarize, it appears that the greatly disconnected geographic distribution of Cedrus species mainly results from the progressive but unavoidable restriction of their habitat area caused by decreasing temperatures in the Northern Hemisphere (figure 10). However, it seems that the three surviving species may have been saved by strong geodynamic events: uplift of the Himalayas (including the Tibet Plateau) for C. deodara, extrusion of the Anatolian Peninsula for C. libani, and brief desiccation of the Mediterranean Sea and maybe Rif orogen for C.atlantica (figure 10). Maybe the geodynamical passive the North American craton did not provide sufficient mountain habitats and boost enough cedar populations there to allow its survival during the Northern Hemisphere glaciations.

\section{Conclusion}

This review shows how much high quality pollen records are needed for reliable past reconstructions of flora, vegetation and climate. In this synthesis, the pollen data show that large number of thermophilous (from megatherm to mesotherm) and hygrophilous taxa successively disappeared from the Mediterranean area throughout the Neogene. However, the great plant biodiversity was not really affected because plant extinctions were rapidly balanced by diversification of new taxa, especially among herbs and shrubs, that maintained the region as an hotspot of plant diversity (Médail \& Quézel, 1997; Médail \& Myers, 2004).

The North Mediterranean plant ecosystems have been deeply modified during the last $23 \mathrm{Ma}$, evolving from forest conditions to open landscapes: Avicennia mangrove disappeared, Glyptostrobus swamps disappeared later too, Mediterranean sclerophyllous ecosystems replaced subtropical evergreen forests, and lastly Artemisia steppes alternated with mesophilous forests during glacialinterglacial cycles. In contrast, the South Mediterranean plant ecosystems continuously sustained an open structure of vegetation with subdesertic associations where the Avicennia mangrove persisted up to the early Pliocene before invasion by the Artemisia steppe. The Mediterranean sclerophyllous plants, already present in the early Miocene, benefited first from the extinction of thermophilous-hygrophilous elements, then fluctuated in relation with temperature variations. They appear, however, to have been advantaged during some phases of high instability in seasonality (high amplitude of obliquity) and low variability in heat (low amplitude of eccentricity). Before its regional extinction, Microtropis fallax can be regarded as a reliable indicator of primitive Mediterranean sclerophyllous populations. At the scale of the whole Late Cenozoic, plant extinctions appear to have been mostly driven along a North-South latitudinal gradient despite some influence of longitude effects (e.g. diversification of rainfall). This general process cannot hide more complex modes that the detailed study of Quaternary glacials-interglacials allows us to decipher (Magri et al., 2017). These include the protective or destructive effects of peculiar geographic situations (e.g. some azonal and irregular strengthening of continental ice during glacials; Tzedakis et al., 2013) or 
progressively acquired ability of some plants or ecosystems to survive in hard conditions (Svenning et al., 2015).

Climatic interpretation of pollen records and their quantification in terms of palaeoclimate parameters emphasize a latitudinal contrast in temperature and in humidity/ dryness, the thermic latitudinal gradient being characterized by a significant increase in the late Miocene towards its modern value. Characterized by elevated temperatures and some seasonality in dryness from 23 to 3.37 Ma, climate evolved with cooler winters and drought concentrated in summers when earliest glacials occurred at $2.6 \mathrm{Ma}$ with generalized dryness and colder conditions alternating with moister and warmer conditions during interglacials. The present-day refuges of some mesophilous taxa, such as the "climate relicts" Zelkova and Pterocarya, may be considered as representative of this highly contrasted history, both from a biogeographical and climatic point of view. The desiccation phase of the Messinian Salinity Crisis did not severely impact the region but forced the subdesertic elements to momentarily migrate northward (Fauquette et al., 2006; Popescu et al., 2007) and offered cedar the opportunity to reach North Africa. The present-day patchy distribution of Cedrus seems to have been influenced by geodynamic events, which offered opportunities to persist, despite repeated coolings.

\section{Ackowledgements}

We express a grateful tribute to Pierre Quézel who still supported our researches with enthusiasm and significantly contributed to them by providing so much information and advices. Some data were provided by E. Russo Ermolli, and information by A. Graham and R.S. Thompson. Since the 1970's, our investigations have been supported and funded by many national (IFB, CNRS, ANR, MISTRALS, Actions Marges, PhD theses) and international (ESF, PROMESS, PhD theses) programs in addition to academic (Universities of Montpellier II and Lyon I) and private support (TOTAL). Many botanical identifications of pollen grains were possible thanks to (1) the use of the Montpellier modern pollen collection (ISEM) and to the continuous availability of its ex-manager J. Chambon, and (2) the willingness of several herbariums (Montpellier, Lyon, Geneva and Paris) to provide flowers for reference pollen. Two anonymous reviewers are particularly thanked for their constructive comments, which significantly improved the manuscript. Dr Keith Richards is warmly acknowledged for editing the English text. This paper is the ISEM contribution $n^{\circ}$ 2018-109 SUD.

\section{References}

Achalhi M., Münch P., Cornée J.-J., Azdimousa A., Melinte-Dobrinescu M., Quillévéré F., Drinia H., Fauquette S., Jiménez-Moreno G., Merzeraud G., Ben Moussa A., El Kharim Y. \& Feddi N., 2016. The late Miocene Mediterranean-Atlantic connections through the North Rifian Corridor: New insights from the Boudinar and Arbaa Taourirt basins (northeastern Rif, Morocco). Palaeogeogr., Palaeoclimatol., Palaeoecol., 459: 131-152.

Alba-Sánchez F., Abel-Schaad D., López-Sáez J.A., Sabariego Ruiz S., Pérez-Díaz S. \& GonzálezHernández A., 2018. Paleobiogeografía de Abies spp. y Cedrus atlantica en el Mediterráneo occidental (península ibérica y Marruecos). Ecosistemas, 27, 1: 26-37.

Armijo R., Meyer B., Hubert A. \& Barka A., 1999. Westward propagation of the North Anatolian fault into the northern Aegean: Timing and kinematics. Geology, 27: 267-270.

Arnaud-Fassetta G., Beaulieu J.-L. de, Suc J.-P., Provansal M., Williamson D., Leveau P., Landuré C., Gadel F., Aloïsi J.-C., Giresse P., Oberlin C. \& Duzer D., 2000. Evidence for an early land use in the Rhône delta (Mediterranean France) as recorded by late Holocene fluvial paleoenvironments (1640-100 B.C.) Geodyn. Acta, 13: 377-389.

Aytug B., 1961. Étude des pollens du genre Cèdre (Cedrus Link.). Pollen et Spores, 3, 1: 47-54.

Bache F., Popescu S.-M., Rabineau M., Gorini C., Suc J.-P., Clauzon G., Olivet J.-L., Rubino J.-L., Melinte-Dobrinescu M.C., Estrada F., Londeix L., Armijo R., Meyer B., Jolivet L., Jouannic G., Leroux E., Aslanian D., Dos Reis A.T., Mocochain L., Dumurdžanov N., Zagorchev I., Lesić V., Tomić D., Çağatay M.N., Brun J.-P., Sokoutis D., Csato I., Ucarkus G. \& Çakir Z., 2012. A two-step process for the reflooding of the Mediterranean after the Messinian Salinity Crisis. Bas. Res., 24: 125-153.

Bache F., Gargani J., Suc J.-P., Gorini C., Rabineau M., Popescu S.-M., Leroux E., Do Couto D., Jouannic G., Rubino J.-L., Olivet J.-L., Clauzon G., Dos Reis A.T. \& Aslanian D., 2015. Messinian evaporite deposition during sea level rise in the Gulf of Lions (Western Mediterranean). Mar. Pet. Geol., 66: 262-277.

Bachiri Taoufiq N., Bahroun N. \& Suc J.-P., 2008. Les environnements continentaux du corridor rifain (Maroc) au Miocène supérieur d'après la palynologie. Geodiversitas, 30, 1: 41-58.

Barka A.A., 1992. The North Anatolian fault zone. Ann. Tectonicae, 6: 164-195.

Barrón E., Rivas-Carballo R., Postigo-Mijarra J., Alcalde-Olivares C., Vieira M., Castro L., Pais J. \& Valle-Hernández M., 2010. The Cenozoic 
vegetation of the Iberian Peninsula: A synthesis. Rev. Palaeobot. Palynol., 162: 382-402.

Barrón E., Postigo-Mijarra J. \& Casas-Gallego M., 2016. Late Miocene vegetation and climate of the La Cerdanya Basin (eastern Pyrenees, Spain). Rev. Palaeobot. Palynol., 235: 99-119.

Bassil J., Naveau A., Fontaine C., Grasset L., Bodin J., Porel G., Razack M., Kazpard V. \& Popescu S.-M., 2016. Investigation of the nature and origin of the geological matrices rich in selenium within the Hydrogeological Experimental Site of Poitiers, France. C. R. Geoscience, 348: 598-608.

Beaudouin C., Suc J.-P., Acherki N., Courtois L., Rabineau M., Aloïsi J.-C., Sierro F.J. \& Oberlain C., 2005a. Palynology of the northwestern Mediterranean shelf (Gulf of Lions): First vegetational record for the last climatic cycle. Mar. Pet. Geol., 22, 6-7: 845-863.

Beaudouin C., Suc J.-P., Cambon G., Touzani A., Giresse P., Pont D., Aloïsi J.-C., Marsset T., Cochonat P. Duzer D. \& Ferrier J., 2005b. Present-day rhythmic deposition in the Grand Rhône prodelta (NW Mediterranean) according to high-resolution pollen analyses. Journ. Coast. Res., 21: 292-306.

Beaudouin C., Suc J.-P., Escarguel G., Arnaud M. \& Charmasson S., 2007. The significance of pollen signal in present-day marine terrigenous sediments: The example of the Gulf of Lions (western Mediterranean Sea). Geobios, 40: 159-172.

Beaulieu J.-L. de, Miras Y., Andrieu-Ponel V. \& Guiter F., 2005. Vegetation dynamics in northwestern Mediterranean regions: Instability of the Mediterranean bioclimate. Plant Biosyst., 139: 114-126.

Berger A., 1990. Paleo-insolation at the Plio-Pleistocene boundary. Paléobiol. cont., 17: 1-24.

Bertini A., 2010. Pliocene to Pleistocene palynoflora and vegetation in Italy: State of the art. Quat. Intern., 225: 5-24.

Bertini A. \& Martinetto E., 2011. Reconstruction of vegetation transects for the Messinian-Piacenzian of Italy by means of comparative analysis of pollen, leaf and carpological records. Palaeogeogr. Palaeoclimatol., Palaeoecol., 304: 230-246.

Bessais E. \& Cravatte J., 1988. Les écosystèmes végétaux pliocènes de Catalogne méridionale. Variations latitudinales dans le domaine nord-ouest méditerranéen. Geobios, 21, 1: 49-63.

Bessedik M., 1981. Une mangrove à Avicennia L. en Méditerranée occidentale au Miocène inférieur et moyen. Implications paléogéographiques. $C$. $R$. Acad. Sc. Paris, ser. II, 293: 469-472.

Bessedik M., 1983. Le genre Buxus L. (Nagyipollis Kedves 1962) au Tertiaire en Europe occidentale : évolution et implications paléogéographiques. Pollen et Spores, 25, 3-4: 461-486.

Bessedik M., 1984. The early Aquitanian and upper Langhian - lower Serravallian environments in the Northwestern Mediterranean region. Paléobiol. cont., 14, 2: 153-179.

Bessedik M. \& Cabrera L., 1985. Le couple récif-mangrove à Sant Pau d'Ordal (Vallès-Penedès, Espagne), témoin du maximum transgressif en Méditerrranée nord-occidentale (Burdigalien supérieur-Langhien inférieur). Newsl. Stratigr., 14, 1: 20-35.

Biltekin D., Popescu S.-M., Suc J.-P., Quézel P., JiménezMoreno G., Yavuz N. \& Çağatay M.N., 2015 Anatolia: A long-time plant refuge area documented by pollen records over the last 23 million years. Rev. Palaeobot. Palynol., 215: 1-22.

Brenac P., 1984. Végétation et climat de la Campanie du Sud (Italie) au Pliocène final d'après l'analyse pollinique des dépôts de Camerota. Ecol. Medit. 10, 3-4: 207-216.

Bruch A., 2004. The botanical and the morphological approach in Neogene palynology - a practical comparison. Acta Palaeobot., 44, 1: 87-91.

Cambon G., Suc J.-P., Aloïsi J.-C., Giresse P., Monaco A., Touzani A., Duzer D. \& Ferrier J., 1997. Modern pollen deposition in the Rhône delta area (lagoonal and marine sediments), France. Grana, 36: 105-113.

Capella W., Barhoun N., Flecker R., Hilgen F.J., Kouwenhoven T., Matenco L.C., Sierro F.J., Tulbure M.A., Yousfi M.Z. \& Krijgsman W., 2018. Palaeogeographic evolution of the late Miocene Rifian Corridor (Morocco): reconstructions from surface and subsurface data. Earth-Sci. Rev., 180: 37-59.

Capella W., Matenco L., Dmitrieva E., Roest W.M.J., Hessels S., Hssain M., Chakor-Alami A., Sierro F.J. \& Krijgsman W., 2017. Thick-skinned tectonics closing the Rifian Corridor. Tectonophysics, 710711: 249-265.

Cheddadi R., Fady B., François L., Hajar L., Suc J.-P., Huang K., Demarteau M., Vendramin G.G. \& Ortu E., 2009. Putative glacial refugia of Cedrus atlantica deduced from Quaternary pollen records and modern genetic diversity. J. Biogeogr., 36, 7: 1361-1371.

Chikhi H., 1992. Une palynoflore méditerranéenne à subtropicale au Messinien pré-évaporitique en Algérie. Géol. Médit., 19, 1: 19-30.

Combourieu-Nebout N., 1990. Les cycles glaciairesinterglaciaires en région méditerranéenne de 2,4 à 1,1 Ma : analyse pollinique de la série de Crotone (Italie méridionale). Paléobiol. cont., 17: 35-59.

Combourieu-Nebout N., 1993. Vegetation response to upper Pliocene glacial/interglacial cyclicity in the central Mediterranean. Quat. Res., 40: 228-236.

Combourieu-Nebout N., Fauquette S. \& Quézel P., 2000. What was the late Pliocene Mediterranean climate like: a preliminary quantification from vegetation. Bull. Soc. géol. France, 171, 2: 271-277.

Combourieu-Nebout N., Bertini A., Russo-Ermolli E., Peyron O., Klotz S., Montade V., Fauquette S., Allen J., Fusco F., Goring S., Huntley B., Joannin S., Lebreton V., Magri D., Martinetto E., Orain R. \& Sadori L., 2015. Climate changes in the central Mediterranean and Italian vegetation dynamics since the Pliocene. Rev. Palaeobot. Palynol., 218: 127-147.

Combourieu-Nebout N., Peyron O., Dormoy I., Desprat S., Beaudouin C., Kotthoff U. \& Marret F., 2009. Rapid climatic variability in the west Mediterranean during the last 25000 years from high resolution pollen data. Clim. Past, 5: 503-521.

Cravatte J. \& Suc J.-P., 1981. Climatic evolution of North-Western Mediterranean area during Pliocene and Early Pleistocene by pollen-analysis and forams of drill Autan 1. Chronostratigraphic correlations. Pollen et Spores, 23, 2: 247-258.

Denk T., Frotzler N. \& Davitashvili N., 2001 Vegetational patterns and distribution of relict taxa in humid temperate forests and wetlands of Georgia (Tanscaucasia). Biol. J. Linn. Soc., 72: 287-332. 
Di Pasquale G., Garfi G. \& Quézel P., 1992. Sur la présence d'un Zelkova nouveau en Sicile sud-orientale (Ulmaceae). Biocosme mésogéen, 8-9: 401-409.

Erdtman G., 1952. Pollen morphology and plant taxonomy. Angiosperms (An Introduction to Palynology). Almqvist \& Wiksell, Stockholm, 539 p.

Fauquette S., Guiot J. \& Suc J.-P., 1998a. A method for climatic reconstruction of the Mediterranean Pliocene using pollen data. Palaeogeogr., Palaeoclimatol., Palaeoecol., 144: 183-201.

Fauquette S., Quézel P., Guiot J. \& Suc J.-P., 1998b. Signification bioclimatique de taxons-guides du Pliocène méditerranéen. Geobios, 31, 2: 151-169.

Fauquette S., Suc J.-P., Guiot J., Diniz F., Feddi N., Zheng Z., Bessais E. \& Drivaliari A., 1999. Climate and biomes in the West Mediterranean area during the Pliocene. Palaeogeogr., Palaeoclimatol., Palaeoecol., 152: 15-36.

Fauquette S. \& Bertini A., 2003. Quantification of the northern Italy Pliocene climate from pollen data evidence for a very peculiar climate pattern. Boreas, 32: 361-369.

Fauquette S., Suc J.-P., Bertini A., Popescu S.-M., Warny S., Bachiri Taoufiq N., Perez Villa M.-J., Chikhi H., Subally D., Feddi N., Clauzon G. \& Ferrier J., 2006. How much did climate force the Messinian salinity crisis? Quantified climatic conditions from pollen records in the Mediterranean region. Palaeogeogr., Palaeoclimatol., Palaeoecol., 238: 281-301.

Fauquette S., Suc J.-P., Jiménez-Moreno G., Micheels A., Jost A., Favre E., Bachiri-Taoufiq N., Bertini A., Clet-Pellerin M., Diniz F., Farjanel G., Feddi N. \& Zheng, Z., 2007. Latitudinal climatic gradients in Western European and Mediterranean regions from the Mid-Miocene (c. $15 \mathrm{Ma}$ ) to the Mid-Pliocene (c. $3.5 \mathrm{Ma}$ ) as quantified from pollen data. In: Williams M., Haywood A., Gregory J. \& Schmidt D.N. (eds.), Deep-time perspectives on climate change: Marrying the signal from computer models and biological proxies, Micropaleontol. Soc., Geol. Soc. London, Spec. Publ.: 481-502.

Fauquette S., Bernet M., Suc J.-P., Grosjean A.-S., Guillot S., van der Beek P., Jourdan S., Popescu S.-M., Jiménez-Moreno G., Bertini A., Pittet B., Tricart P., Dumont T., Schwartz S., Zheng Z., Roche E., Pavia G. \& Gardien V., 2015. Quantifying the Eocene to Pleistocene topographic evolution of the southwestern Alps, France and Italy. Earth Planet. Sci. Lett., 412: 220-234.

Feddi N., Fauquette S. \& Suc J.-P., 2011. Histoire plio-pléistocène des écosystèmes végétaux de Méditerranée sud-occidentale: apport de l'analyse pollinique de deux sondages en mer d'Alboran. Geobios, 44: 57-69.

Ferguson D.K., 1967. On the phytogeography of coniferales in the European Cenozoic. Palaeogeogr., Palaeoclimatol., Palaeoecol., 3: 73-110.

Follieri M., Magri D. \& Sadori L., 1986. Late Pleistocene Zelkova extinction in Central Italy. New Phytol., 103: 269-273.

González-Sampériz P., Leroy S.A.G., Carrión J.S., Fernández S., García-Antón M., Gil-García M.J., Uzquiano P., Valero-Garcés B. \& Figueiral I., 2010. Steppes, savannahs, forests and phytodiversity reservoirs during the Pleistocene in the Iberian Peninsula. Rev. Palaeobot. Palynol., 162: 427-457.
Graham A., 1999. Late Cretaceous and Cenozoic history of North American vegetation. Oxford University Press, New York - Oxford, 350 p.

Grimm G.W. \& Denk T., 2012. Reliability and resolution of the coexistence approach - A revalidation using modern-day data. Rev. Palaeobot. Palynol., 172: 33-47.

Grimm G.W., Bouchal J.M., Denk T. \& Potts A., 2016. Fables and foibles: A critical analysis of the Palaeoflora database and the Coexistence Approach for palaeoclimate reconstruction. Rev. Palaeobot. Palynol., 233: 216-235.

Grootes P.M. \& Stuiver M., 1997. Oxygen 18/16 variability in Greenland snow and ice with $10^{-3}$ - to $10^{-5}$ year time resolution. Journ. Geophys. Res., 102, C12: 26455-26470.

Head M.J. \& Gibbard P.L., 2005. Early-Middle Pleistocene transitions: An overview and recommendation for the defining boundary. In: Head M.J. \& Gibbard P.L. (eds.), Early-Middle Pleistocene Transitions: The Land-Ocean Evidence, Geol. Soc. London, Spec. Publ., 247: 1-18.

Hou H.-Y., 1983. Vegetation of China with reference to its geographical distribution. Ann. Missouri Bot. Gard., 70, 3: 509-548.

Hsü J., 1983. Late Cretaceous and Cenozoic vegetation in China, emphasizing their connections with North America. Ann. Missouri Bot. Gard., 70: 490-508.

Kuang K., Zheng Z. \& Cheddadi R., 2008. Atlas of plants distributions and related climate in China. China Review Academic Publishers, Hong Kong, $277 \mathrm{p}$.

Jalut G., Dedoubat J.J., Fontugne M. \& Otto T., 2009. Holocene circum-Mediterranean vegetation changes: Climate forcing and human impact. Quat. Intern., 200: 4-18.

Jiménez-Moreno G. \& Suc J.-P., 2007. Middle Miocene latitudinal climatic gradient in Western Europe: Evidence from pollen records. Palaeogeogr., Palaeoclimatol., Palaeoecol., 253: 224-241.

Jiménez-Moreno G., Popescu S.-M., Ivanov D. \& Suc J.-P., 2007. Neogene flora, vegetation and climate dynamics in Central Eastern Europe according to pollen records. In: Williams M., Haywood A., Gregory J. \& Schmidt D.N. (eds.), Deep-time perspectives on climate change: Marrying the signal from computer models and biological proxies, Micropaleontol. Soc., Geol. Soc. London, Spec. Publ.: 393-406.

Jiménez-Moreno G., de Leeuw A., Mandic O., Harzhauser M., Pavelić D., Krijgsman W. \& Vranjković, 2009. Integrated stratigraphy of the Early Miocene lacustrine deposits of Pag island (SW Croatia): Palaeovegetation and environmental changes in the Dinaride Lake System. Palaeogeogr., Palaeoclimatol., Palaeoecol., 280: 193-206.

Jiménez-Moreno G., Fauquette S. \& Suc J.-P., 2010. Miocene to Pliocene vegetation reconstruction and climate estimates in the Iberian Peninsula from pollen data. Rev. Palaeobot. Palynol., 162: 403-415.

Jiménez-Moreno G., Burjachs F., Expósito I., Oms O., Carrancho A., Villalaín J.J., Agustí J., Campeny G., Gómez de Soler B. \& van der Made J., 2013. Late Pliocene vegetation and orbital-scale climate changes from the western Mediterranean area. Global Planet. Change, 108: 15-28.

Jiménez-Moreno G., Alçiçek H., Alçiçek M.C., van den Hoek Ostende L. \& Wesselingh F.P., 2015. Vegetation and climate changes during the late 
Pliocene and early Pleistocene in SW Anatolia, Turkey. Quat. Res., 84: 448-456.

Joannin S., Bassinot F., Combourieu-Nebout N., Peyron O. \& Beaudouin C., 2011. Vegetation response to obliquity and precession forcing during the MidPleistocene Transition in Western Mediterranean region (ODP site 976). Quat. Sci.Rev., 30: 280-297.

Joannin S., Ciaranfi N. \& Stefanelli S., 2008. Vegetation changes during the late Early Pleistocene at Montalbano Jonico (province of Matera, southern Italy) based on pollen analysis. Palaeogeogr. Palaeoclimatol., Palaeoecol., 270: 92-101.

Jolivet L., Augier R., Robin C., Suc J.-P. \& Rouchy J.-M., 2006. Lithospheric-scale geodynamic context of the Messinian salinity crisis. Sedim. Geol., 188189: 9-33.

Julià Bruguès R. \& Suc J.-P., 1980. Analyse pollinique des dépôts lacustres du Pléistocène inférieur de Banyoles (Bañolas, site de la Bòbila Ordis Espagne): un élément nouveau dans la reconstitution de l'histoire paléoclimatique des régions méditerranéennes d'Europe occidentale. Geobios, 3, 1: 5-19.

Karacaş, Ç., Armijo, R., Lacassin, R., Suc, J.-P. \& Melinte-Dobrinescu, M.C., 2018. Crustal strain in the Marmara pull-apart region associated with the propagation process of the North Anatolian Fault. Tectonics, 37: 1507-1523.

Klotz S., Fauquette S., Combourieu Nebout N., Uhl D., Suc J.-P. \& Mosbrugger V., 2006. Seasonality intensification and long-term winter cooling as a part of the late Pliocene climate development. Earth Planet. Sci. Lett., 241: 174-187.

Kovar-Eder J., Kvaček Z., Martinetto E. \& Roiron P., 2006. Late Miocene to Early Pliocene vegetation of southern Europe (7-4 Ma) as reflected in the megafossil plant record. Palaeogeogr., Palaeoclimatol., Palaeoecol., 238: 321-339.

Lancelot J.R., Reille J.-L. \& Wezel F.C., 1977. Étude morphologique et radiochronologique de zircons détritiques des flyschs "numidien" et "gresomicacé”. Bull. Soc. géol. France, ser. 7, 19: 773-780.

Laskar J., Robutel P., Joutel F., Gastineau M., Correia A.C.M. \& Levrard B., 2004. A long-term numerical solution for the insolation quantities of the Earth. Astron. \& Astrophys., 428: 261-285.

Le Dantec C., Suc J.-P., Suballyova D., Vernet J.-L., Fauquette S. \& Calleja M., 1998. Évolution floristique des abords de la mare de Grammont (Montpellier, sud de la France) depuis un siècle: disparition d'Isoetes setacea Lam. Ecol.Medit., 24, 2: $159-170$.

Leopold E.B. \& Denton M.F., 1987. Comparative age of grassland and steppe East and West of the Northern Rocky Mountains. Ann. Missouri Bot. Gard., 74: 841-867.

Leroy S.A.G., 2007. Progress in palynology of the Gelasian-Calabrian Stages in Europe: Ten messages. Rev. micropaléontol., 50: 293-308.

Lisiecki L. \& Raymo M.E., 2005. A Pliocene-Pleistocene stack of 57 globally distributed benthic $\delta^{18} \mathrm{O}$ records. Paleoceanography, 20: PA1003.

Lobreau-Callen D. \& Suc J.-P., 1972. Présence de pollens de Microtropis fallax (Celastraceae) dans le Pléistocène inférieur de Celleneuve (Hérault). C.R. Acad. Sc. Paris, ser. D, 275: 1351-1354.

Magri D., 2012. Quaternary history of Cedrus in Southern Europe. Ann. Bot., 2: 57-66.
Magri D., Di Rita F., Aranbarri J., Fletcher W. \& González-Sampériz P., 2017. Quaternary disappearance of tree taxa from Southern Europe: Timing and trends. Quat. Sci. Rev., 163: 23-55.

Magri D. \& Parra I., 2002. Late Quaternary western Mediterranean pollen records and African winds. Earth Planet. Sci. Lett., 200: 401-408.

Martinetto E., Momohara A., Bizzarri R., Baldanza A., Delfino M., Esu D. \& Sardella R., 2015. Late persistence and deterministic extinction of "humid thermophilous plant taxa of East Asian affinity" (HUTEA) in southern Europe. Palaeogeogr., Palaeoclimatol., Palaeoecol., 467: 211-231.

Médail F., 2018. Pierre Quézel (1926-2015), une vie et œuvre scientifiques entre Méditerranée et Sahara. Ecol. Medit., 44(2): 5-22.

Médail F. \& Diadema K., 2009. Glacial refugia influence plant diversity patterns in the Mediterranean basin. J. Biogeogr., 36: 1333-1345.

Médail F. \& Myers N., 2004. Mediterranean Basin. In: Mittermeier R.A., Robles Gil P., Hoffmann M., Pilgrim J., Brooks T., Mittermeier C.G., Lamoreux J. \& da Fonseca G.A.B. (eds.). Hotspots revisited: Earth's biologically richest and most endangered terrestrial ecoregions. CEMEX (Monterrey), Conservation International (Washington) \& Agrupación Sierra Madre (Mexico): 144-147.

Médail F. \& Quézel P., 1997. Hot-Spots analysis for conservation of plant biodiversity in the Mediterranean Basin. Ann. Missouri Bot. Gard., 84, 1: 112-127.

Melinte-Dobrinescu M.C., Suc J.-P., Clauzon G., Popescu S.-M., Armijo R., Meyer B., Biltekin D., Çağatay M.N., Ucarkus G., Jouannic G., Fauquette S. \& Çakir Z., 2009. The Messinian Salinity Crisis in the Dardanelles region: Chronostratigraphic constraints. Palaeogeogr., Palaeoclimatol., Palaeoecol., 278: 24-39.

Merrill E.D. \& Freeman F.L., 1940. The Old Word species of the Celastraceous genus Microtropis Wallich. Proc. Am. Acad. Arts and Sc., 73, 10: 271-310.

Meulenkamp J.E. \& Sissingh W., 2003. Tertiary palaeogeography and tectonostratigraphic evolution of the Northern and Southern peri-Tethys platforms and the intermediate domains of the African-Eurasian convergent plate boundary zone. Palaeogeogr., Palaeoclimatol., Palaeoecol., 196: 209-228.

Mosbrugger V. \& Utescher T., 1997. The coexistence approach: A method for quantitative reconstructions of tertiary terrestrial palaeoclimate data using plant fossils. Palaeogeogr., Palaeoclimatol., Palaeoecol., 134: 61-86.

Muller S.D., Rhazi L., Andrieux B., Bottollier-Curtet M., Fauquette S., Saber E.-R., Rifai N. \& DaoudBouattour A., 2015. Vegetation history of the western Rif mountains (NW Morocco): Origin, late-Holocene dynamics and human impact. Veget. Hist. Archaeobot., 24: 487-501.

Naud G. \& Suc J.-P., 1975. Contribution à l'étude paléofloristique des Coirons (Ardèche): premières analyses polliniques dans les alluvions sous-basaltiques et interbasaltiques de Mirabel (Miocène supérieur). Bull. Soc. géol. France, (ser. 7), 17, 5: 820-827.

Nix H., 1982. Environmental determinants of biogeography and evolution in Terra Australis. In: Barker W.R. \& Greenslade P.J.M. (eds.), Evolution of the flora and fauna of arid Australia. Peacock Publishing, Frewville: 47-66. 
Pons A., 1964. Contribution palynologique à l'étude de la flore et de la végétation pliocènes de la région rhodanienne. Ann. Sci. Nat. Bot., sér. 12, 5: 499-722.

Pons A., 1998. L'histoire du genre Cedrus d'après les données paléobotaniques disponibles. Forêt médit., 19, 3: 236-242.

Popescu S.-M., 2006. Late Miocene and early Pliocene environments in the southwestern Black Sea region from high-resolution palynology of DSDP Site 380A (leg 42B). Palaeogeogr., Palaeoclimatol., Palaeoecol., 238: 64-77.

Popescu S.-M., Suc J.-P. \& Loutre M.-F., 2006. Early Pliocene vegetation changes forced by eccentricityprecession: Example from Southwestern Romania. Palaeogeogr., Palaeoclimatol., Palaeoecol., 238: 340-348.

Popescu S.-M., Suc J.-P., Melinte M., Clauzon G., Quillévéré F. \& Sütő-Szentai M., 2007. Earliest Zanclean age for the Colombacci and uppermost Di Tetto formations of the "latest Messinian" northern Apennines: New palaeoenvironmental data from the Maccarone section (Marche Province, Italy). Geobios, 40: 359-373.

Popescu S.-M., Biltekin D., Winter H., Suc J.-P., Melinte-Dobrinescu M.C., Klotz S., CombourieuNebout N., Rabineau M., Clauzon G. \& Deaconu F., 2010. Pliocene and Lower Pleistocene vegetation and climate changes at the European scale: Long pollen records and climatostratigraphy. Quat. Intern., 219: 152-167.

Popescu S.-M., Dalibard M., Suc J.-P., Barhoun N., Melinte-Dobrinescu M.C., Bassetti M.A., Deaconu F., Head M.J., Gorini C., Do Couto D., Rubino J.-L., Auxietre J.-L. \& Floodpage J., 2015. Lago Mare episodes around the Messinian-Zanclean boundary in the deep southwestern Mediterranean. Mar. Pet. Geol., 66: 55-70.

Popescu S.-M., Melinte-Dobrinescu M.C. \& Suc J.-P., 2016. Objective utilization of data from DSDP Site 380 (Black Sea). Terra Nova, 28: 228-229.

Postigo-Mijarra J.M., Morla C., Barrón E., MoralesMolino C. \& García S., 2010. Patterns of extinction and persistence of Arctotertiary flora in Iberia during the Quaternary. Rev. Palaeobot. Palynol., 162: 416-426.

Qiao C.-Y., Ran J.-H., Li Y. \& Wang X.-Q., 2007. Phylogeny and biogeography of Cedrus (Pinaceae) inferred from sequences of seven paternal chloroplast and maternal mitochondrial DNA regions. Ann. Bot., 100: 573-580.

Quézel P., 1998. Cèdres et cédraies du pourtour méditerranéen: signification bioclimatique et phytogéographique. Forêt médit., 19, $3:$ 243-260.

Quézel P. \& Médail F., 2003. Écologie et biogéographie des forêts du bassin méditerranéen. Elsevier, Paris, $571 \mathrm{p}$.

Quézel P., Barbero M., Bonin G. \& Loisel R., 1980. Essais de corrélations phytosociologiques et bioclimatiques entre quelques structures actuelles et passées de la végétation méditerranéenne. Nat. Monsp., out ser.: 89-100.

Quézel P., Di Pasquale G. \& Garfi G., 1993. Découverte d'un Zelkova en Sicile sud-orientale. Incidences biogéographiques et historiques. C. R.Acad. Sci. Paris, ser. III, 316: 21-26.

Romagny A., Münch Ph., Cornée J.-J., Corsini M., Azdimousa A., Melinte-Dobrinescu M.C., Drinia H., Bonno M., Arnaud N., Monié P., Quillévéré F. \& Ben Moussa A., 2014. Late Miocene to present-day exhumation and uplift of the Internal Zone of the Rif chain: Insights from low temperature thermochronometry and basin analysis. Journ. Geodyn., 77: 39-55.

Rouse G.E. \& Srivastava S.K., 1972. Palynological zonation of Cretaceous and Early Tertiary rocks of the Bonnet Plume Formation, Northeastern Yukon, Canada. Can. J. Earth Sci., 9: 1163-1179.

Russo Ermolli E., 1994. Analyse pollinique de la succession lacustre pléistocène du Vallo di Diano (Campanie, Italie). Ann. Soc. géol. Belgique, 117, 2: 333-354.

Russo Ermolli E. \& Cheddadi R., 1997. Climatic reconstruction during the Middle Pleistocene: A pollen record from Vallo di Diano (Southern Italy). Geobios, 30: 735-744.

Ryan W.B.F., Carbotte S.M., Coplan J.O., O'Hara S., Melkonian A., Arko R., Weissel R.A., Ferrini V., Goodwillie A., Nitsche F., Bonczkowski J. \& Zemsky R., 2009. Global Multi-Resolution Topography synthesis. Geochem. Geophys. Geosyst., 10, Q03014, doi:10.1029/2008GC002332.

Salpin M., Schnyder J., Baudin F., Suan G., Suc J.-P., Popescu S.-M., Fauquette S., Reinhardt L., Schmitz M. \& Labrousse L., accepted. Evidence for subtropical warmth in Canadian Arctic (BeaufortMackenzie, Northwest Territories, Canada) during the early Eocene. In: Refining the Arctic, Geol. Soc. Amer. Books.

Shackleton N.-J., Hall M.A. \& Pate D., 1995. Pliocene stable isotope stratigraphy of Site 846. Proc. Ocean Drill. Progr., Sci. Res., 138, U.S. Gov. Print. Off.: 337-355.

Shatilova I., Mchedlishvili N., Rukhadze L. \& Kvavadze E., 2011. The history of the flora and vegetation of Georgia (South Caucasus). Georgian National Museum, Tbilisi, 200 p.

Sivak J., 1975. Les caractères de diagnose des grains de pollen à ballonnets. Pollen et Spores, 18, 3: 349-421.

Suan G., Popescu S.-M., Suc J.-P., Schnyder J., Fauquette S., Baudin F., Yoon D., Piepjohn K., Sobolev N. \& Labrousse L., 2017. Subtropical climate conditions and mangrove growth in Arctic Siberia during the early Eocene. Geology, 45, 6: 539-542.

Subally D. \& Quézel P., 2002. Glacial or interglacial: Artemisia, a plant indicator with dual responses. Rev. Palaeobot. Palynol., 120: 123-130.

Suc J.-P., 1973. Étude palynologique des marnes de Celleneuve (Pléistocène inférieur). Hérault. Bull. Assoc. fr. ét. Quaternaire, 1: 13-24.

Suc J.-P., 1974. Pollens attribuables aux Agavaceae dans le Pliocène du Languedoc. Pollen et Spores, 16, 4: 493-498.

Suc J.-P., 1976a. Apports de la palynologie à la connaissance du Pliocène du Roussillon (sud de la France). Geobios, 9, 6: 741-771.

Suc J.-P., 1976b. Quelques taxons-guides dans l'étude paléoclimatique du Pliocène et du Pléistocène inférieur du Languedoc (France). Rev. Micropaléontol., 18, 4: 246-255.

Suc J.-P., 1978a. Présence de pollens d'Hamamelis (Hamamelidaceae, Angiospermae) dans le Pliocène du sud de la France. Geobios, 11, 3: 399-403.

Suc J.-P., 1978b. Analyse pollinique de dépôts pliopléistocènes du sud du Massif basaltique de l'Escandorgue (série de Bernasso - Lunas, Hérault France). Pollen et Spores, 20, 4: 497-512.

Suc J.-P., 1981. La végétation et le climat du Languedoc (sud de la France) au Pliocène moyen d'après la palynologie. Paléobiol. cont., 12, 1: 7-26. 
Suc J.-P., 1984. Origin and evolution of the Mediterranean vegetation and climate in Europe. Nature, 307: 429-432.

Suc J.-P., 1989. Distribution latitudinale et étagement des associations végétales au Cénozoïque supérieur dans l'aire ouest-méditerranéenne. Bull. Soc. Géol. France, ser. 8, 5, 3: 541-550.

Suc J.-P. \& Bessedik M., 1981. A methodology for Neogene palynostratigraphy. In: Martinell J. (ed.), International symposium on concepts and methods in paleontology, Barcelone, 5-8 May 1981: 205-208.

Suc J.-P. \& Bessais E., 1990. Pérennité d'un climat thermo-xérique en Sicile, avant, pendant, après la crise de salinité messinienne. C. R. Acad. Sci. Paris, (ser. 2), 310: 1701-1707.

Suc J.-P. \& Cravatte J., 1982. Étude palynologique du Pliocène de Catalogne (nord-est de l'Espagne). Paléobiol. cont., 13, 1 : 1-31.

Suc J.-P. \& Popescu S.-M., 2005. Pollen records and climatic cycles in the North Mediterranean region since 2.7 Ma. In: Head M.J. \& Gibbard P.L. (eds.), Early-middle Pleistocene transitions: The landocean evidence, Geol. Soc. London, Spec. Publ., 247: 147-158

Suc J.-P., Legigan P. \& Diniz F., 1986. Analyse pollinique de lignites néogènes des Landes: Arjuzanx et Hostens (France). Bull. Inst. Géol. Bassin d'Aquitaine, 40: 53-65.

Suc J.-P., Bertini A., Combourieu-Nebout N., Diniz F., Leroy S., Russo-Ermolli E., Zheng Z., Bessais E. \& Ferrier J., 1995. Structure of West Mediterranean vegetation and climate since $5.3 \mathrm{Ma}$. Acta zool. Cracov., 38, 1: 3-16.

Suc J.-P., Fauquette S., Bessedik M., Bertini A., Zheng Z., Clauzon G., Suballyova D., Diniz F., Quézel P., Feddi N., Clet M., Bessais E., Bachiri Taoufiq N., Méon H. \& Combourieu-Nebout N., 1999. Neogene vegetation changes in West European and West circum-Mediterranean areas. In: Agusti J., Rook L. $\&$ Andrews P. (eds.), Hominid evolution and climate in Europe, 1 Climatic and environmental change in the Neogene of Europe, Cambridge University Press, Cambridge: 370-385.

Suc J.-P., Fauquette S. \& Popescu S.-M., 2004. L'investigation palynologique du Cénozoïque passe par les herbiers. In : Pierrel R. \& Reduron J.-P. (eds.), Actes du colloque «Les herbiers : un outil d'avenir. Tradition et modernité », Villeurbanne, 20-22 November 2002. Association française pour la conservation des espèces végétales, Nancy : 67-87.

Suc J.-P., Combourieu-Nebout N., Seret G., Popescu S.-M., Klotz S., Gautier F., Clauzon G., Westgate J. \& Sandhu A.S., 2010. The Crotone series: A synthesis and new data. Quat. Intern., 219: 121-133.

Svenning J.-C., 2003. Deterministic Plio-Pleistocene extinctions in the European cool-temperate tree flora. Ecol. Lett., 6: 646-653.

Svenning J.-C., Eiserhardt W.L., Normand S., Ordonez A. \& Sandel B., 2017. The influence of paleoclimate on present-day patterns in biodiversity and ecosystems. Ann. Rev. Ecol. Evol. Syst., 46: 551-572.

The Plant List, 2013. Version 1.1. Published on the Internet; http://www.theplantlist.org/

Thompson R.S., 1991. Pliocene environments and climates in the Western United States. Quat. Sci. Rev. 10: 115-132.

Tzedakis P.C., 2007. Seven ambiguities in the Mediterranean palaeoenvironmental narrative. Quat. Sci. Rev., 26: 2042-2066.
Tzedakis P.C., Emerson B.C. \& Hewitt G.M., 2013. Cryptic or mystic? Glacial tree refugia in northern Europe. Trends Ecol. Evol., 28: 696-704.

Utescher T., Bruch A.A., Erdei B., François L., Ivanov D., Jacques F.M.B., Kern A.K., Liu Y.-S.C., Mosbrugger V. \& Spicer R.A., 2014. The coexistence approach-theoretical background and practical considerations of using plant fossils for climate quantification. Palaeogeogr., Palaeoclimatol., Palaeoecol., 410: 58-73.

Van Campo-Duplan M., 1950. Recherches sur la phylogénie des Abiétinées d'après leurs grains de pollen. Trav. Lab. Forest. Toulouse, $1^{\text {re }}$ sect., 2, 4: 9-182.

Velitzelos D., Bouchal J.M. \& Denk T., 2014. Review of the Cenozoic floras and vegetation of Greece. Rev. Palaeobot. Palynol., 204: 56-117.

Vidal J., 1960. La végétation du Laos, $2^{\mathrm{e}}$ partie. Tr. Lab. For. Toulouse, 5, 1, $1^{\text {re }}$ sect., art. 3: 1-582.

Wang C.-W., 1961. The forests of China with a survey of grassland and desert vegetation. Maria Moors Cabot Foundation, 5, Harvard University, Cambridge, Massachussets, $313 \mathrm{p}$.

Wang Y., Zheng J., Zhang W., Li S., Liu X., Yang X. \& Liu Y., 2012. Cenozoic uplift of the Tibetan Plateau: Evidence from the tectonic-sedimentary evolution of the western Qaidam Basin. Geosci. Frontiers, 3, 2: $175-187$.

Warny S., Bart P.J. \& Suc J.-P., 2003. Timing and progression of climatic, tectonic and glacioeustatic influences on the Messinian Salinity Crisis. Palaeogeogr., Palaeoclimatol., Palaeoecol., 202: 59-66.

White F., 1983. The Vegetation of Africa. UNESCO, Paris, $356 \mathrm{p}$.

Zachos J., Pagani M., Sloan L., Thomas E. \& Billups K., 2001. Trends, rhythms, and aberrations in global climate 65 Ma to present. Science, 292: 686-693.

Zagwijn W.H., 1960. Aspects of the Pliocene and Early Pleistocene vegetation in The Netherlands. Meded. Geol. Sticht., C, 3, 1, 5: 5-78.

Zheng Z., 1990. Végétations et climats néogènes des Alpes maritimes franco-italiennes d'après les données de l'analyse palynologique. Paléobiol. cont., 17: 217-244.

Zheng Z., Huang K., Xy Q., Lu H., Cheddadi R., Luo Y., Beaudouin C., Luo C., Zheng Y., Li C., Wei J. \& Du C., 2008. Comparison of climatic threshold of geographical distribution between dominant plants and surface pollen in China. Sci. China Ser. D-Earth Sci., 51, 8: 1107-1120.

Zhou Z.-K., Su T. \& Huang Y.-J., 2018. Neogene paleoenvironmental changes and their role in plant diversity in Yunnan, South-Western China. In: Hoorn C., Perrigo A. \& Antonelli A. (eds.), Mountains, climate and biodiversity, Wiley \& Sons, Oxford, 29: 449-458.

Zohary M., 1973. Geobotanical foundations of the Middle East. Vol. 2, Fischer G. Verlag, Stuttgart, $739 \mathrm{p}$. 